\title{
TRADEMARK APOLOGETIC JUSTICE: CHINA'S TRADEMARK JURISPRUDENCE ON REPUTATIONAL HARM
}

\author{
Professor Xuan-Thao Nguyen*
}

"[A] reputation, like a face, is the symbol of its possessor and creator, and another can use it only as a mask." - Judge Learned Hand

"The quality of a trademark owner's reputation should lie within his own control." 2

\section{INTRODUCTION}

Will Apple be ordered to apologize for its unauthorized use of the trademark "iPad" in Shenzhen, China?" Will Apple face massive confiscation of infringing "iPad" products in China?"

* Professor of Law, SMU Dedman School of Law; former IP Associate, Fried, Frank, Harris, Shriver \& Jacobson (NYC) and Pryor Cashman Sherman \& Flynn (NYC). Many thanks to Pei-Chih "Peggy" Ho, Class of 2011, SMU Dedman School of Law, and Sara Alyn Horner, Class of 2012, for their superb assistance. A version of this Article was presented at Washington University School of Law in January 2012. Special thanks to Erik Darwin Hille and Khai-Leif Nguyen-Hille for their love, patience, and support.

1. Yale Elec. Corp. v. Robertson, 26 F.2d 972, 974 (2d Cir. 1928). Judge Learned Hand's phrase has been repeatedly quoted by subsequent courts. See, e.g., Commc'ns Satellite Corp. v. Comcet, Inc., 429 F.2d 1245, 1250 (3d Cir. 1970); Holiday Inns of Am., Inc. v. B \& B Corp., 409 F.2d 614, 616 (1st Cir. 1969); Polaroid Corp. v. Polaraid, Inc., 319 F.2d 830, 835 (4th Cir. 1963); Fleischmann Distilling Corp. v. Maier Brewing Co., 314 F.2d 149, 159 n.14A (9th Cir. 1963); Safeway Stores, Inc. v. Safeway Props., Inc., 307 F.2d 495, 498 (2d Cir. 1962); Ambassador E., Inc. v. Orsatti, Inc., 257 F.2d 79, 82 (3d Cir. 1958).

2. Prof'l Golfers Ass'n of Am. v. Bankers Life \& Cas. Co., 514 F.2d 665, 671 (5th Cir. 1975).

3. See generally Liau Yun Qing, Reports: iPads Taken off Shelves in China over Trademark Dispute, ZDNeT AsIA (Feb. 14, 2012, 2:48 PM), http://www.zdnetasia.com/rep orts-ipads-taken-off-shelves-in-china-over-trademark-dispute-62303847.htm (discussing Apple's trademark dispute with a Chinese company); Francis Bea, Apple Trademark Battle Threatens to Halt iPad Sales in China, Digital Trends (Feb. 7, 2012),http://www.digital trends.com/international/apple-trademark-battle-threatens-to-halt-ipad-sales-in-china/ (same).

4. See Francis Bea, Chinese Officials Raid Retailers, Confiscate iPads Following 
Appropriation of another's name and reputation without authorization has long been recognized as an injury. ${ }^{5}$ Trademark law does not tolerate usurpation of the reputation embodied in a trademark or name that misleads or confuses the public. ${ }^{6}$ The injured person or business can seek remedies in the form of injunctive relief ${ }^{7}$ and monetary damages, ${ }^{8}$ which are rooted in property interest theory ${ }^{9}$ and damages in torts liability rules, ${ }^{10}$

Trademark Ruling Against Apple, DigitAL TRENDS (Feb. 13, 2012), http://news.yahoo.com /chinese-officials-raid-retailers-confiscate-ipads-following-trademark-213014316.html (discussing the confiscation of Apple products by Chinese officials as a result of a court's finding of trademark infringement by Apple).

5. Taussig v. Wellington Fund, Inc., 313 F.2d 472, 478 (3d Cir. 1963) ("[A]ppropriation of another's name and reputation 'is an injury, even though the borrower does not tarnish it, or divert any sales by its use; for a reputation, like a face, is the symbol of its possessor and creator, and another can use it only as a mask. And so it has come to be recognized that, unless the borrower's use is so foreign to the owner's as to insure against any identification of the two, it is unlawful." (quoting Yale Elec. Corp., 26 F.2d at 974)).

6. Ga. Pac. Consumer Prods., Ltd. P'ship v. Von Drehle Corp., 618 F.3d 441, 455 (4th Cir. 2010) (holding that the plaintiff G-P "ha[d] proffered sufficient evidence for a reasonable jury to find that the likelihood of confusion among such restroom visitors will adversely affect G-P's reputation among its laborers, lenders, investors, or other groups with whom G-P interacts" and recognizing that "without the ability to control the quality of the toweling used in [G-P's branded] Dispensers, G-P is subject to the risk of injury to the reputation of the G-P Marks."). See generally 15 U.S.C. § 1125(a) (2012) (creating civil liability for the use of words or symbols that are likely to cause consumer confusion as to source).

7. Cytosport, Inc. v. Vital Pharm., Inc., 348 F. App'x 288, 289 (9th Cir. 2009) (affirming injunctive relief granted by the district court upon a finding that the plaintiff was likely to succeed on the merits and suffer irreparable harm in absence of preliminary injunction); Opticians Ass'n of Am. v. Indep. Opticians of Am., 920 F.2d 187, 196 (3d Cir. 1990) (holding that lack of control over one's trademark "creates the potential for damage to... reputation[, which] constitutes irreparable injury for the purpose of granting a preliminary injunction in a trademark case."); U.S. Polo Ass'n, Inc. v. PRL USA Holdings, Inc., 800 F. Supp. 2d 515, 542 (S.D.N.Y. 2011) (granting permanent injunction that prohibited the corporate infringer from using the "U.S. POLO ASSN." name in conjunction with a double horsemen mark in men's fragrances).

8. See Ramada Inns v. Gadsden Motel Co., 804 F.2d 1562, 1565 (11th Cir. 1986) (affirming the lower court's ruling on the use of lost royalties to determine the actual damages incurred by the plaintiff from the unauthorized use of plaintiff's trademark by a former franchisee).

9. Friend v. H. A. Friend \& Co., 416 F.2d 526, 533 (9th Cir. 1969) (stating that a trademark right "is in the nature of a property right based on common law" and affirming the district court's granting of an injunction against the defendant's use of the mark “"Banner"'); Champions Golf Club, Inc. v. Sunrise Land Corp., 846 F. Supp. 742, 757 (W.D. Ark. 1994) (holding that the plaintiff is "entitled to an injunction in this case to protect its valuable property right and to terminate or prevent irreparable harm to that right").

10. Common law torts for trademark infringement have been codified in federal trademark and unfair competition law or the Lanham Act. See e.g., Two Pesos, Inc. v. Taco Cabana, Inc., 505 U.S. 763, 785 (1992) ("The general proof and measure of damages in a 
respectively. Even if the plaintiff were successful in obtaining both injunctive relief and monetary damages, the remedies received do not truly address the harm to trademark reputation because they do not consider that the public was also harmed by the defendant's misleading conduct. ${ }^{11}$ What remedy may be appropriate in addition to injunction and monetary damages? What remedy may be appropriate that would take the harm done to both the public and the plaintiff into consideration? The answer lies in China's jurisprudence on trademark reputation and apologetic justice. ${ }^{12}$

trademark action is governed by the law of damages of tort actions."); Broan Mfg. Co. v. Assoc. Distrib., Inc., 923 F.2d 1232, 1235 (6th Cir. 1991) ("Under general tort principles . . . 'the infringer/tortfeasor is liable for all injuries caused to plaintiff by the wrongful act, whether or not actually anticipated or contemplated by the defendant when it performed the acts of infringement."'). Id. (quoting 2 J. THOMAS MCCARTHY, MCCARTHY ON Trademarks AND UnFair COMPETITION $\S 30: 27$ (2d ed. 1984)).

11. Vornado Air Circulation Sys, Inc. v. Duracraft Corp., 58 F.3d 1498, 1508 (10th Cir. 1995) (affirming that the "core concepts of trademark protection are that consumers not be confused, misled, or deceived as to whose product they are buying, that sellers' goodwill - or investment in their reputation for quality - be protected, and that competition thereby be enhanced"). The remedies, however, do not concern the public. For instance, a jury in a trademark case is instructed to award damages to the plaintiff if there is approximate cause between the defendant's conduct and the plaintiff's injury to reputation or goodwill. See generally Aronowitz v. Health-Chem Corp., 513 F.3d 1229, 1241 (11th Cir. 2008) (affirming a jury verdict of $\$ 25,000$ in damages in a trademark case where the jury was instructed, "'damages sustained by the plaintiff' include 'all elements of injury to the business of the trademark owner proximately resulting from the infringer's wrongful acts[,]' such as the costs of corrective advertising or injury to business reputation or goodwill.") (quoting Ramada Inns, 804 F.2d at 1564-65).

12. This Article addresses trademark reputation under China's trademark jurisprudence. For normative reputation law under defamation and libel, see Article 101 of the General Principles of Civil Law of the People's Republic of China, which provides that "[c]itizens and legal persons shall enjoy the right of reputation. The personality of citizens shall be protected by law, and the use of insults, libel or other means to damage the reputation of citizens or legal persons shall be prohibited." General Principles of the Civil Law of the People's Republic of China (promulgated by the Nat'l People's Cong., Apr. 12, 1986, effective Jan. 1, 1987) (LawInfochina), available at http://www.lawinfochina.com/dis play.aspx?lib=law\&id=1165. Article 140 of the Opinions of the Supreme People's Court on Several Issues concerning the Implementation of the General Principles of Civil Law of the People's Republic of China (for trial implementation) provides that:

Where anyone spreads the privacy of another person in writing or verbally, fabricates facts to overtly smear the personality of another person, or damages another person's reputation by ways such as insulting or slandering, if there are certain consequences, it shall be determined as an infringement upon a citizen's right of reputation. Where anyone derogates from or slanders the reputation of a legal person in writing or verbally, causing damage to the legal person, it shall be determined as an infringement upon the right of reputation of the legal person.

Opinions of the Supreme People's Court on Several Issues concerning the Implementation of the Civil Law of the People's Republic of China (promulgated by the Sup. People's Ct., 
This is a rather ironic assertion, given that most of the attention on China has been negative, focusing overwhelmingly on the piracy of U.S. intellectual property rights. ${ }^{13}$

China has continued to surprise the international community in its efforts to transform the country from being the factory of the world into the global innovation center. ${ }^{14}$ While foreigners look at China as a piracy epicenter, China has unleashed its power to develop new trademark jurisprudence through statutes, judicial directives from the Supreme People's Court and written decisions published by the lower people's courts. $^{15}$ China's trademark jurisprudence treats injuries to trademark reputation as harmful to both the plaintiff and society. Accordingly, Chinese law gives the court discretion to order the defendant to make a public apology in a newspaper or trade journal in cases where the defendant intentionally or maliciously harmed the plaintiff's reputation by misleading the public through unauthorized use of the plaintiff's trademark or name. ${ }^{16}$ In a public apology, the defendant admits to the infringing conduct, acknowledges the trademarks or names owned by the plaintiff, apologizes for the wrongdoing and promises not to engage in the unauthorized use of the trademark or name in the future. ${ }^{17}$ Generally, the content of a public apology must be approved by the court. If the defendant fails to make the public apology in a timely manner, the court may authorize the plaintiff to publish a public apology in the defendant's name and charge the expenses to the defendant. ${ }^{18}$ A public apology is not

Jan. 26, 1988, effective Jan. 26, 1998) (LawInfochina), available at http://www.lawinfo china.com/display.aspx?lib=law\&id=3700 [hereinafter Opinions of the Sup. People's Ct. on Civil Law]; see also Benjamin L. Liebman, Innovation Through Intimidation: An Empirical Account of Defamation Litigation in China, 47 HARV. INT'L L.J. 33 (2006) (analyzing the types of defamation litigation in China as a case study of the complex and evolving roles of courts, media, and government in Chinese civil litigation).

13. See generally Kenneth L. Port, A Case Against the ACTA, 33 Cardozo L. ReV. 1131,1167 n.169 (2012) (noting that reports have portrayed China as the main culprit for piracy and arguing that the data on piracy is exaggerated); Geoffrey Scott, A Protocol for Evaluating Changing Global Attitudes Toward Innovation and Intellectual Property Regimes, 32 U. PA. J. INT'L. L. 1165, 1264-67 (2011) (evaluating China's piracy problem).

14. Anil K. Gupta \& Haiyan Wang, China as an Innovation Center? Not So Fast, WALl ST. J. (July 28, 2011), available at http://online.wsj.com/article/SB100014240531 11903591104576469670146238648 .html ("China's R\&D expenditure increased to $1.5 \%$ of GDP in 2010 from $1.1 \%$ in 2002 , and should reach $2.5 \%$ by 2020 . Its share of the world's total R\&D expenditure grew to $12.3 \%$ in 2010 from $5.0 \%$ in 2002 , placing it second only to the U.S., whose share remained steady at $34-35 \%$. According to UNESCO, China now employs more people in science and technology research than any other country.").

15. See infra Part I.

16. See infra Parts II-III.

17. See infra Parts II-III.

18. See infra Parts II-III. 
in lieu of, but rather in addition, to injunction, damages, and litigation cost remedies, as China has already fully embraced property and liability rules by directing the defendant to cease the infringing conduct and pay monetary damages. ${ }^{19}$

A closer look at China's trademark jurisprudence reveals a robust and complex development of these laws and the increasingly important judicial role in combating trademark reputation harm. ${ }^{20}$ Unlike the United States, where the comprehensive trademark statutes provide all the answers relating to the unauthorized use of a trademark or name, ${ }^{21}$ China has three separate bodies of laws: Trademark Law, Unfair Competition Law, and Civil Law. ${ }^{22}$ When pieced together, they present a rich body of law, which includes trademark reputation law. China's three laws cannot be analyzed separately and in isolation from the Supreme People Court's judicial directives. Judicial directives and official interpretations of these three laws, in combination with lower courts' published opinions applying the three laws, show the making of a dynamic trademark jurisprudence. This jurisprudence addresses the harm done to trademark reputation caused by the defendant's willful conduct of misleading the public. ${ }^{23}$ A public apology as a remedy is evidence of China's trademark jurisprudence's consideration for the public; the public plays a role in the remedy of the harm because the public has been misled by the defendant's conduct. Thus, justice has been achieved for the plaintiff and the public.

China's trademark jurisprudence and apologetic justice forces U.S. scholars and policymakers to contemplate Judge Learned Hand's keen observation about trademark reputation and focus on the question of remedy. This does not mean that the United States will import Chinese trademark jurisprudence and apologetic justice. However, in the age of globalization and the rise of China's Century, ${ }^{24}$ knowledge of China's legal

19. See infra Parts II-III.

20. Experts on Chinese Intellectual Property laws, specifically trademark law, often only focus on one body of law, China's Trademark Law, and thus provide an incomplete account of China's trademark jurisprudence. See generally Patricia Marquez, Trademark: A Comparative Look at China and the United States, 14 TOURO INT'L L. REV. 334, 336-37 (2011) ("Because China employs a first to file system, it does not usually recognize unregistered marks."); Anne M. Wall, Intellectual Property Protection in China: Enforcing Trademark Rights, 17 MARQ. INTELL. Prop. L. Rev. 341, 372 (2006) (noting that because Chinese law follows "the first-to-file principle," foreign trademark owners have been caught by surprise as they enter China's market without prior registration of trademark rights; they cannot rectify the problem of already existing registration of the trademark for the relevant goods).

21. See, e.g., 15 U.S.C. $\S 1051$ (2012) (regulating the trademark registration process).

22. See infra Part I.

23. See infra Part I.

24. See Edward Friedman, Will 21st Century Be China's?, The Diplomat, (Nov. 19, 
system is indispensable. After all, contrary to misunderstandings about China, ${ }^{25}$ the country is no stranger to trademark concepts. ${ }^{26}$ Names and symbols, along with their associated reputations, are an integral part of the Chinese social fabric. ${ }^{27}$

The Article proceeds as follows. Part I discusses the three bodies of law constituting China's trademark jurisprudence by tracing the development of Trademark Law, Anti-Unfair Competition Law, and Civil Law. All of these laws contain relevant provisions pertaining to trademark reputation and remedies, including injunctions, damages, and public apology to eliminate any bad effects. As the China Supreme People's Court has a significant role in shaping trademark jurisprudence and apologetic justice, Part I analyzes judicial directives that provide guidance and instructions to the lower courts in addressing trademark reputation remedies.

An analysis of only statutes and judicial directives, however, does not provide an accurate understanding of China's vibrant development of trademark jurisprudence on reputation and apologetic justice. Accordingly, Part II analyzes judicial decisions rendered by the Chinese courts in trademark reputation cases. Judicial decisions from different levels of the people's court explain the facts, describe the injuries, apply the law, and provide the reasoning for appropriate remedies. If the finding establishes that the infringer did not willfully or maliciously use the trademark or name to mislead the public, the courts will not order a public apology. In this type of case, only injunction and damages are warranted. In other words, if

2011), available at http://thediplomat.com/china-power/will-21st-century-be-china's/ (observing that the prediction that the 21 st century will belong to China was "premised on the idea that the 20th century was the American century and that U.S. predominance would be replaced by that of China").

25. Dalila Hoover, Coercion Will Not Protect Trademark Owners in China, but an Understanding of China's Culture Will: A Lesson the United States Has to Learn, 15 MARQ. InTELL. Prop. L. Rev. 325, 343-45 (2011) (blaming Chinese cultural mores for the lack of trademark protection and enforcement).

26. Ke Shao, Look at My Sign!-Trademarks in China from Antiquity to the Early Modern Times, 87 J. PAT. \& Trademark OfF. Soc'y 654 (2005) (demonstrating that the trademark concept is not foreign in China by reconstructing the evolving trademark concept from the perspective of "self" and individual rights, explaining the social functions of trademarks, and analyzing trademark regulations and protection in pre-modern imperial era).

27. Oded Shenkar, The Chinese Century: The Rising Chinese EConomy and its Impact on the Global Economy, The Balance of Power and Your Job 157-58 (2005) (observing that " $[\mathrm{t}]$ he Chinese themselves are... very brand conscious, a legacy of Confucian hierarchy and of their imperial past where rank was prominently displayed on bureaucrats' clothing," and therefore the recent effort of building and cultivating Chinese brands "fits with the government's strategy of consolidating strategic industries . . . to create national champions that can hold their own in global markets and . . to restore its imperial glory."). 
the public has not been harmed, there is no need to have the public involved in healing through reading apologies in newspapers or trade publications.

What is the content of a public apology in a trademark case and what does a public apology entail? Part III provides several actual apologies published by individual and entity infringers in newspapers and trade journals. They are illuminating examples where the infringers - in writing and in the public forum - acknowledge the plaintiff's exclusive right in a trademark or name, admit the wrongdoing, apologize for the conduct, and promise not to commit infringing conduct in the future. These newspapers and trade journals are available in print and online for the public to read.

Part IV inspects U.S. law and its treatment of injury to trademark reputation. Compared to China, where injunction and damages are routinely granted to the prevailing plaintiff, U.S. law does not authorize courts to grant an automatic injunction upon finding that the plaintiff has succeeded on the merits. Damages are difficult to prove in U.S. trademark cases. In addition, only two percent of U.S. trademark cases advance to trial and only some of those cases receive damage awards. Most significantly, U.S. law does not recognize harm to the public. The courts only provide injunctive relief and damages, if any. Harm to trademark reputation, particularly in cases where the infringer maliciously or willfully misleads the public, is harmful to both the plaintiff and the public. China's trademark jurisprudence and apologetic justice offer a model for the United States to contemplate and serve as an opportunity to reflect on Judge Learned Hand's astute observation on injury to trademark reputation.

Whether the United States will consider apologetic justice in trademark reputation cases is a question for further debate. At the very least, U.S. businesses should not be surprised that Proview Technology, the Chinese company and plaintiff in a trademark infringement action against Apple for the use of the name "iPad," is demanding an apology in addition to injunction and damages. ${ }^{28}$ Knowledge of China's jurisprudence is essential in our globally competitive and fast-changing world. ${ }^{29}$

28. Rick Burgess, Apple Sued for \$1.6 Billion for Using "iPad” in China, Apology Requested, ТЕснSрот (Feb. 9, 2012, 7:30 AM), available at http://www.techspot.co $\mathrm{m} /$ news/47381-apple-sued-for-16-billion-for-using-ipad-in-china-apology-requested.html (reporting that plaintiff, owner of the registered trademark "IPAD" since 2000, brought trademark infringement suit against Apple; the lower people's court in Shenzhen has ruled in favor of the plaintiff and Apple has appealed the case to the Higher Court). For more information on the case, see also Dave Smith, Is iPad 3 in Jeopardy? Apple Could Lose \$1.6B in China Trademark Lawsuit, InT'L Bus. Times (Feb. 7, 2012, 11:21 AM), available at http://www.ibtimes.com/articles/294485/20120207/ipad-3-apple-billion-china-trademarklawsuit.htm.

29. Matt Peckham, iPads Snatched by Chinese Authorities, Trademark Dispute Turns 


\section{THREE LAWS ON TRADEMARK REPUTATION}

China is a civil law country where statutory laws and regulations are the authoritative body of law. ${ }^{30}$ Unlike the United States, China does not follow precedent based upon court decisions. ${ }^{31}$ This does not mean courts in China do not participate in the development of law. The Chinese Supreme People's Court plays a very significant role in shaping jurisprudence. $^{32}$ For example, the Supreme People's Court provides interpretations of China's Trademark Law. ${ }^{33}$ The Court's interpretations are authoritative and supersede any antecedent inconsistent regulations on trademarks. ${ }^{34}$

A comprehensive understanding of Chinese jurisprudence relating to

Tactical, PCWORLD (Feb. 13, 2012, 9:10 AM), available at http://www.pcworld.com/articl e/249853/ipads snatched by chinese authorities trademark dispute turns tactical.html (reporting that many believed that "Äpple's in the wrong here, and could end up paying dearly for it" and that "Apple seems to be trampling" on Chinese trademark rights). The lower people's court in Shenzhen has ordered an injunction against Apple and has begun to confiscate Apple's iPad infringing products sold in some Chinese cities. See Liau Yun Qing, Apple to Lose iPad Trademark in China, ZDNet (Dec. 7, 2011, 9:00 PM), http://www.zdnetasia.com/report-apple-to-lose-ipad-trademark-in-china-62303147.htm (reporting the Shenzhen Court's ruling that Apple had no rights to the iPad trademark in China).

30. Guangjian Tu, China's New Conflicts Code: General Issues and Selected Topics, 59 AM. J. COMP. L. 563, 573 (2011) (noting that China historically is a civil law country); Charlie Xiao-chuan Weng, To Be, Rather than to Seem: Analysis of Trustee Fiduciary Duty in Reorganization and Its Implications on the New Chinese Bankruptcy Law, 45 INT'L LAW. 647, 670 n.186 (2011) (explaining that the "main source of law [in China] is statutes" and that "judicial precedents have hardly any binding effect").

31. Kimberly N. Van Voorhis \& Christie Yang, Recent Developments in Patent Law World Wide, 997 PLI/PAT 405, 419 n.58 (2010) ("As a civil law country court decisions in China have little or no precedential effect, and decisions are rarely published."); Andrew J. Green, Tort Reform with Chinese Characteristics: Towards a "Harmonious Society" in the People's Republic of China, 10 SAN DiEgo INT'L J. 121, 136 (2008) (explaining that courts in China "do not play the role in developing law that they do in the United States and other common law countries.").

32. Green, supra note 31, at 136 (noting that in China's Tort Law Reform, the Chinese Supreme People's Court "has displayed considerable ability in establishing legal rules through its power of judicial interpretation.").

33. The Interpretation by the Supreme People's Court Concerning the Application of Laws in the Trial of Cases of Civil Disputes Arising from Trademarks, (promulgated by the Adjudication Comm. of the Sup. People's Ct., Oct. 12, 2002, effective Oct. 16, 2002), [hereinafter Trademark Law Interpretation]. For a more comprehensive understanding of the role of China Supreme People's Court and its interpretations, see generally Li Wei, Judicial Interpretation in China, 5 WilliametTe J. INT'L L. \& DisP. ReSOL. 87 (1997).

34. Trademark Law Interpretation, supra note 33, at art. 24 ("Where any of the previously promulfated provisions is inconsistent with the present Interpretation, the present Interpretation shall prevail."). 
trademark reputation requires an examination of Chinese laws beyond focusing on the most obvious body of law-China's Trademark Law. ${ }^{35}$ The other two bodies of law-China's Anti-Unfair Competition Law ${ }^{36}$ and Civil Law $^{37}$ - contain provisions addressing trademark reputational harm caused by unauthorized use of names. ${ }^{38}$ These three laws must be analyzed together with related Supreme People's Court judicial directives.

\section{A. China's Trademark Law and the Supreme People's Court}

Some scholars have painstakingly studied historical records and evidence to demonstrate that China has a long history of trademark concepts and practices. ${ }^{39}$ In modern times, ${ }^{40}$ the People's Republic of China celebrated the thirtieth anniversary of the passage of its trademark statutes in 2012. ${ }^{41}$ Much progress has been made through the lens of

35. Trademark Law of the People's Republic of China (promulgated by the Standing Comm. Nat'l People's Cong., Aug 23, 1982, effective Mar. 1, 1983), available at http://www.ccpit-patent.com.cn/references/Trademark_law_China.htm (China) [hereinafter China's Trademark Law].

36. Law Against Unfair Competition of the People's Republic of China (promulgated by the Standing Comm. Nat'l People's Cong., Sept. 2, 1993, effective Sept. 2, 1993) (China), available at http://www.ccpit-patent.com.cn/references/Law_Against_Unfair_ Competition_China.htm.

37. General Principles of the Civil Law of the People's Republic of China (promulgated by Nat'l People's Cong., Apr. 12, 1986, effective Jan. 1, 1987), available at http://en.chinacourt.org/public/detail.php?id=2696 (China) [hereinafter China's Civil Law].

38. China's Civil Law, supra note 37. China's Civil Law has one hundred and fifty-six Articles adopted in 1986 that became effective January 1, 1987:

Article 1: This Law is formulated in accordance with the Constitution and the actual situation in our country, drawing upon our practical experience in civil activities, for the purpose of protecting the lawful civil rights and interests of citizens and legal persons and correctly adjusting civil relations, so as to meet the needs of the developing socialist modernization.

Article 2: The Civil Law of the People's Republic of China shall adjust property relationships and personal relationships between civil subjects with equal status, that is, between citizens, between legal persons and between citizens and legal persons.

China's Civil Law, supra note 37, at art. 1-2.

39. See generally Shao, supra note 26, at 654. The Qing Dynasty enacted intellectual property law that is similar to law found in the West. Also, during the Republic of China (1912-49), Copyright Law was enacted in 1928, Trademark Law in 1930, and Patent Law in 1944. See generally Chengsi Zheng, The Textbook on Intellectual Property Law (1993).

40. In this context, "modern times" refers to after the founding of the People's Republic of China in 1949. See generally Weiqiu Long, Intellectual Property in China, 31 St. MARY's L.J. 63, 65-66 (1999) (detailing the present legal system in China).

41. China's Trademark Law was first adopted at the 24th Session of the Standing 
trademark law and practice in China.

In 1982, ten years after President Nixon's historic visit, China adopted the Trademark Law. ${ }^{42}$ It is unsurprising that China adopted the first Trademark Law in $1982^{43}$ because Deng Xiaoping had opened the country to foreign investment in $1979 .{ }^{44}$ The Coca-Cola Company was one of the very first foreign companies to establish its brand name and trademarked soft drinks in China. It began with permission only to sell imported CocaCola products to foreigners at designated hotels and stores, and then later gained government approval to build bottling plants, obtain distribution rights, and sell Coca-Cola products directly to Chinese consumers. ${ }^{45}$

China's Trademark Law was substantially revised in $1993^{46}$ and $2001^{47}$ to expand the scope of protection and be in compliance with the World Trade Organization (WTO) Agreement on Trade-Related Aspects of

Committee of the Fifth National People's Congress on August 23, 1982. Amendment to China's Trademark Law or "Decision on Revising the Trademark Law of the People's Republic of China" was adopted at the 30th Session of the Standing Committee of the Seventh National People's Congress on Feb. 22, 1993. China's Trademark Law was amended again according to the "Decision on Revising the Trademark Law of the People's Republic of China" adopted at the 24th Session of the Standing Committee of the Ninth National People's Congress on Oct. 27, 2001. China's Trademark Law, supra note 35.

42. Jerome A. Cohen, Ted Kennedy's Role in Restoring Diplomatic Relations with China, 14 N.Y.U. J. Legis. \& Pub. Pol'y 347, 351-52 (2011) (recounting events leading up to President Nixon's visit to China).

43. The year 1982 was significant in China, as that is when the fifth Constitution was adopted, which included intellectual property rights. See Long, supra note 40, at 66-68 (observing that the fifth Constitution was viewed as a new constitution because it was considerably different from the former constitution and it included intellectual property rights).

44. Immanuel C.Y. Hsü, The Rise of Modern China 858 (6th ed. 2000) (observing that after President Nixon's visit, China's trade with the United States rapidly grew from $\$ 92$ million in 1972 to " $\$ 1,189$ million in $1978, \$ 5,478$ million in $1981, \$ 8$ billion in 1986 , and $\$ 13.5$ billion in 1988 , amounting to approximately 10 percent of China's total foreign trade.").

45. Drake Weisert, Coca-Cola in China, Quenching the Thirst of a Billion, THE CHINA BuSINESS REV. 2001 (July-Aug. 2001), available at https://www.chinabusinessreview.com/ public/0107/weisert.html (recounting the history of Coca-Cola in China from early 1980's to the present time).

46. Linda Yueh, Patent Laws and Innovation in China, 29 INT'L ReV. L. \& ECON. 304, 305 (2009) (explaining that there were "significant revisions in 1993, which permit[ted] registration and provide[d] protection for service marks and also enact[ed] criminal sanctions for trademark infringement."); see also Nadine Farid Johnson, Pursuing Trademark Reform in China, 3 LANDSLIDE 6, 7 n.2 (Jan.-Feb. 2011) (discussing the achievements made in the 1993 China Trademark revision).

47. See generally Ruixue Ran, Well-Known Trademark Protection in China: Before and After the TRIPS Amendments to China's Trademark Law, 19 UCLA PAC. BASIN L.J. 231 (2002) (explaining China's 2001 amendments to trademark law). 
Intellectual Property (TRIPS), as China acceded to the WTO in 2001. ${ }^{48}$ Under China's Trademark Law, trademark rights begin with registration of the trademark, not with the use of the trademark in commerce. ${ }^{49}$ China's Trademark Law refuses registration of a trademark that is identical or similar to an already registered trademark, ${ }^{50}$ and also prohibits the infringing use of a mark that is identical or similar to a registered trademark. $^{51}$ These prohibitions are consistent with China as a first-to-file

48. See Stephanie M. Greene, Protecting Well-Known Marks in China: Challenges for Foreign Mark Holders, 45 AM. Bus. L.J. 371, 376-77 (2008) (observing that China adopted the trademark amendments to bring its law in compliance with TRIPS by broadening the types of trademarks eligible for protection and improving remedies in trademark infringement cases); Joseph A. Massey, The Emperor is Far Away: China's Enforcement of Intellectual Property Rights Protection, 1986-2006, 7 CHI. J. INT'L. L. 231, 236 (2006) ("With its accession to the WTO in December 2001, China made further changes to its ... trademark . . laws and regulations, and issued new implementing rules.").

49. A registered trademark means a trademark that has been approved and registered by the Trademark Office, which includes goods mark, service mark, collective mark and certification mark. China's Trademark Law, supra note 35, at art. 3. The trademark registrant shall enjoy an exclusive right to use the trademark, which shall be protected by law. China's Trademark Law, supra note 35, at art. 3. "Any natural person, legal person or other organization, intending to acquire the exclusive right to use a trademark for goods produced, manufactured, processed, selected or marketed by him," shall file an application for the registration of the goods trademark with the Trademark Office. China's Trademark Law, supra note 35, at art. 4.

50. See China's Trademark Law, supra note 35 at art. 28:

Where a trademark the registration of which has been applied for is not in conformity with the relevant provisions of this Law, or it is identical with or similar to the trademark of another person that has, in respect of the same or similar goods, been registered or, after examination, preliminarily approved, the Trademark Office shall refuse the application and shall not publish the said trademark.an application for registration of a trademark is not in compliance with the relevant provisions of this Law, or if the trademark is identical with or similar to a trademark of another person that has been registered or accepted in respect of [sic] identical or similar goods, the Trademark Office shall refuse to accept the application and shall not publish the same.

51. A person infringes the exclusive right to use a registered trademark if he:

(1) uses a trademark that is identical with or similar to a registered trademark in relation to identical or similar goods without the consent of the owner of the registered trademark;

(2) offers for sale goods that are in infringement of the exclusive right to use a registered trademark;

(3) counterfeits, or makes without authorization, representations of a registered trademark of another person, or offers for sale such representations;

(4) changes a registered trademark and put [sic] goods bearing the changed trademark on [sic] market without consent of the owner of the registered trademark; or

(5) causes, in other respects, prejudice to the exclusive right of another person to use a registered trademark.

China's Trademark Law, supra note 35, at art. 52. 
country, meaning trademark rights begin with registration of a trademark. ${ }^{52}$

Moreover, China's Trademark Law grants greater protection for trademarks that are recognized as well-known. ${ }^{53}$ This protection also extends to non-registered, well-known trademarks. ${ }^{54}$ This means the registration application of a well-known trademark by a third-party will be denied, and the use of the trademark by a third party will be prohibited. ${ }^{55}$ In a trademark infringement action, the prevailing plaintiff is entitled to injunctive relief, damages, and reasonable litigation costs. ${ }^{56}$

Following the adoption of China's Trademark Law in 1982, the China Supreme People's Court has played a critical role in molding trademark jurisprudence. ${ }^{57}$ Indeed, the Court now provides a set of Interpretations on

52. Eu Jin Chua, The Laws of the People's Republic of China: An Introduction for International Investors, 7 CHI. J. INT'L L. 133, 150 (2006) (explaining that, under the firstto-file system, if there is a conflict between two competing applicants, the person who files first has priority over the subsequent filer); see also Katherine C. Spelman, Combating Counterfeiting, in Global Trademark AND Copyright 1995: Management and Protection (Practising Law Institute ed. 1995) 417 PLI/PAT 309, 322 (1995) ("Under Chinese trademark law, registration is required for protection, and China has followed a 'first-to-file' trademark system.").

53. See China's Trademark Law, supra note 35, at art. 13 ("A trademark shall not be registered and its use shall be prohibited where the trademark constitutes a reproduction, an imitation, or a translation, of a well-known trademark of another person already registered in China and is likely to mislead the public and damage the interests of the owner of the registered well-known trademark, if the trademark is the subject of an application for registration in respect of goods which are not identical or similar to the goods to which the well-known trademark applies."); China's Trademark Law, supra note 35, at art. 14 ("The following factors shall be considered in determining a well-known trademark: (1) the reputation of the trademark in the relevant sector of the public; (2) duration of use of the trademark; (3) duration, degree, and geographical scope of any publicity for the trademark; (4) history of protection of the trademark as a well-known trademark; and (5) other factors contributing to the reputation of the trademark."); see also Leah Chan Grinvald, A Tale of Two Theories of Well-Known Marks, 13 VAND. J. ENT. \& TeCH. L. 1, 31-33 (2010) (analyzing Chinese cases related to well-known trademarks such as Starbucks and Viagra).

54. See China's Trademark Law, supra note 35, at art. 13; see also Chua, supra note 52, at 150 ("For trademarks that have not been registered in China (because registration is not available), the Trademark Law also gives protection to well known trademarks.").

55. See Ai Guo Zhang, The Judicial Determination and Protection of Well-known Marks in China in the $21^{\text {st }}$ Century, 48 U. Louisville L. Rev. 959, 961-63 (2010) (providing a history of well-known trademark protection adopted by China after it became a member of the Paris Convention and the WTO).

56. See China's Trademark Law, supra note 35, at art. 56.

57. See generally Xue Hanqin \& Jin Qian, International Treaties in the Chinese Domestic Legal System, 8 CHINESE J. INT'L L. 299, 314 (2009) (recognizing that China's Supreme People's Court has even a stronger role in jurisprudence development because "[ $\mathrm{t}]$ he Chinese legal system is not a case law system: there is no such legal principle as stare decisis in its judicial practice. Judicial directives given by the Supreme People's Court therefore play a significant role in guiding the lower courts in the interpretation and application of law."). 
Trademark Law, ${ }^{58}$ including remedies.

In the Interpretations, the prevailing plaintiffs have the right to select either actual damages or an accounting of the defendant's profits. ${ }^{59}$ Specifically, the Interpretations instruct how losses suffered by the plaintiff in trademark cases can be calculated. ${ }^{60}$ Likewise, the Interpretations explain how profits gained by the infringer should be quantified. ${ }^{61}$ If damages cannot be ascertained, a statutory damages amount is available under the trademark statute. ${ }^{62}$ In addition, the Supreme People's Court authorizes the lower courts to exercise discretion in determining appropriate damages in cases where damages cannot be assessed. ${ }^{63}$ The parties, however, are free to reach an agreement on the amount of damages. ${ }^{64}$

With respect to an award of reasonable litigation costs incurred in

58. See Trademark Law Interpretation, supra note 33.

59. See Trademark Law Interpretation, supra note 33, at art. 13 ("When determining the compensation liabilities of the infringer on the basis of Article 56, Paragraph 1 of the Trademark Law, the people's court may compute the amount of compensation according to the method of computation as selected by the right holder.").

60. See Trademark Law Interpretation, supra note 33, at art. 15:

The losses incurred from infringement as provided in Article 56, Paragraph 1 of the Trademark Law may be computed as the product of the reduced sales volume of the commodities concerned resulting from the infringement and the unit profit of the commodities which are represented by the registered trademark.

61. See Trademark Law Interpretation, supra note 33, at art. 14 ("The interests obtained from infringement as provided in Article 56, Paragraph 1 of the Trademark Law may be calculated as the product of the sales volume of the infringing commodities and the unit profit of the commodities concerned. In case it is impossible to know the unit profit of the commodity, the unit profit shall be the commodity which is represented by the registered trademark.").

62. See China's Trademark Law, supra note 35, at art. 56 ("Where the profit earned by the infringer or losses suffered by the infringee through the infringement mentioned in the preceding paragraph cannot be determined, the people's court shall grant a compensation not exceeding RMB 500,000 yuan, according to the circumstances of the act of infringement.").

63. See Trademark Law Interpretation, supra note 33, at art. 16 ("In case it is difficult to determine the interests of the infringer gained from the infringement or the losses of the infringed incurred from the infringement, the people's court may determine the amount of compensation according to the claims of the parties concerned or by applying the provisions of Article 56, Paragraph 2 of the Trademark Law ex officio.

When determining the amount of compensation, the people's court shall take into comprehensive consideration of the elements, including the nature, duration and aftermaths of the infringing act, the reputation of the trademark, the amount of royalties for licensing the trademark, the type, time and scope of the license of the trademark, as well as the reasonable expenses for stopping the infringing acts, etc.").

64. See Trademark Law Interpretation, supra note 33, at art. 16 ("Where the parties concerned have come into any agreement with regard to the amount of compensation according to Paragraph 1 of the present Article, such agreement shall be allowed."). 
connection with a trademark infringement action, the China Supreme People's Court authorizes the award to include costs associated with investigation and evidence collection. ${ }^{65}$ Additionally, the lower people's courts may award legal fees, if circumstances permit. ${ }^{66}$

In addressing delay in commencing a trademark infringement action, the Supreme People's Court clarifies that the statute of limitations for trademark infringement is two years. ${ }^{67}$ In the event that the infringing conduct is ongoing and the trademark owner fails to bring an action within the two-year period, the trademark owner may still bring an infringement case and is entitled to injunctive relief. ${ }^{68}$ Compensatory damages in such cases, however, will be calculated for only the two years prior to the filing of the complaint with the court. ${ }^{69}$

Analyzing China's Trademark Law gives an incomplete understanding of Chinese trademark jurisprudence, as the Trademark Law does not address the reputation or goodwill embodied in names that are not registered as trademarks. Nonetheless, it enjoys public recognition. Additionally, Trademark Law does not contain an apology remedy provision. China's Anti-Unfair Competition Law addresses both registered trademarks and unregistered trademarks or names. As to an apology remedy, China's Civil Law includes public apology remedy provisions to eliminate bad effects.

\section{B. China's Anti-Unfair Competition Law and the Supreme People's Court}

In addition to Trademark Law, China's Anti-Unfair Competition Law prohibits conduct that is deemed unfair and damaging to competitors, thereby harming a trademark's reputation. ${ }^{70}$ The Anti-Unfair Competition Law became effective December 1, 1993, after the National People's Congress passed the law three months earlier. "Unfair competition" is

65. See Trademark Law Interpretation, supra note 33, at art. 17 ("The reasonable expenses incurred from stopping infringing acts as provided in Article 56, Paragraph 1 of the Trademark Law include the reasonable expenses paid by the right holder or the entrusted agent thereof for investigating into the infringing acts and obtaining evidences.").

66. Trademark Law Interpretation, supra note 33, at art. 17.

67. Trademark Law Interpretation, supra note 33, at art. 18.

68. Trademark Law Interpretation, supra note 33, at art. 18

69. See Trademark Law Interpretation, supra note 33, at art. 18

70. Law of the People's Republic of China Against Unfair Competition (promulgated by the Standing Comm. Nat'l People's Cong., Sep. 2, 1993, effective Dec. 1, 1993) (Westlaw China) [hereinafter Anti-Unfair Competition Law].

71. See Tianlong Yu, An Anti-Unfair Competition Law Without a Core: An Introductory Comparison Between U.S. Antitrust Law and the New Law of the People's 
broadly defined as activities that damage an individual's or business enterprise's rights and interests, disturb the harmony of social economy and violate the provisions of the Anti-Unfair Competition Law. ${ }^{72}$

Article 5 of the Anti-Unfair Competition Law explicitly prohibits using someone else's registered trademark. ${ }^{73}$ In addition, a careful examination of Article 5 reveals that it does not limit legal protection to registered trademarks, but rather encompasses a broader range of infringing conduct categorized as unfair. ${ }^{74}$ It prohibits anyone from:

using for a commodity without authorization a unique name, package, or decoration of another's famous commodity, or using a name, package or decoration similar to that of another's famous commodity, thereby confusing the commodity with that famous commodity and leading the purchasers to mistake the former for the latter ... . ${ }^{75}$

This means that the protection is extended to unregistered trademarks. It protects the names and the packaging of famous or noted products; ${ }^{76}$ the unauthorized use of such intellectual property is classified as unfair competition. $^{77}$

Most importantly, Article 5 forbids anyone from "using without authorization the name of another enterprise or person, thereby leading people to mistake their commodities for those of the said enterprise or person." ${ }^{, 78}$ In other words, the unauthorized use of a name belonging to an entity in connection with a product that misleads the consumer as to the origin of the product is illegal. $^{79}$ The prohibition extends to the

Republic of China, 4 IND. INT'L \& COMP. L. REv. 315, 315-16 (1994) (providing background of the Chinese Anti-Unfair Competition Law).

72. Anti-Unfair Competition Law, supra note 70, at art. 2.

73. Anti-Unfair Competition Law, supra note 70, at art. 5 ("Managers should not use the following unfair methods in their business transactions which can damage other competitors: 1 . to feign the others' registered trade mark.").

74. Anti-Unfair Competition Law, supra note 70, at art. 5.

75. Anti-Unfair Competition Law, supra note 70, at art. 5.

76. Emphasis is added to highlight that the protection here is not for famous or wellknown trademarks, but unregistered trademarks and trade dress of famous or noted products. See Interpretation of the Supreme People's Court on Some Matters about the Application of Law in the Trial of Civil Cases Involving Unfair Competition (promulgated by Sup. People's Ct., Jan. 12, 2007) http://www.wipo.int/wipolex/en/text.jsp?file_id=182407 (China) [hereinafter AUCL Interpretation] (detailing interpretations of case law for the, "purpose of correctly hearing the civil cases involving unfair competition, lawfully protecting the legitimate rights and interests of business operators, and maintaining the order of market competition ....").

77. Anti-Unfair Competition Law, supra note 70, at art. 5(2).

78. Anti-Unfair Competition Law, supra note 70, at art. 5(3).

79. Anti-Unfair Competition Law, supra note 70, at art. 5(3). 
unauthorized use of a personal name in connection with a product that causes consumer confusion. ${ }^{80}$ Fraudulent misrepresentation of the quality of a product is also identified as an act of unfair competition. ${ }^{81}$ Remedies for violation of Article 5 include injunction, confiscation of illegal profits gained by the defendant, treble accounting of profits, cancellation of business license, and possible criminal prosecution. ${ }^{82}$

The China Supreme People's Court provides authoritative judicial directives to lower courts in interpreting Anti-Unfair Competition Law. ${ }^{83}$ The Supreme People's Court did not issue the AUCL Interpretation until early $2007,{ }^{84}$ fourteen years after the enactment of the Anti-Unfair Competition Law in $1993 .{ }^{85}$ Perhaps the Court needed time to observe and collect experience from actual cases, since the Court had at one point announced that its AUCL Interpretation was constituted in accordance with specific bodies of law "and in combination with the experiences and actual situation of the trial practice." 86

The AUCL Interpretation instructs lower courts on the protection of unregistered name or packaging of famous or well-known products, as stated in Article 5 of the Anti-Unfair Competition Law. ${ }^{87}$ In addition, the Court has compiled a list of excluded features that the lower courts should not consider in analyzing whether a product should be designated as "wellknown." 88 The AUCL Interpretation explains that a "well-known product"

80. Anti-Unfair Competition Law, supra note 70, at art. 5(3).

81. Anti-Unfair Competition Law, supra note 70, at art. 5(4) (prohibiting others from "forging or counterfeiting authentication marks, famous-and-excellent-product marks or other product quality marks on their commodities, forging the origin of their products or making false and misleading indications as to the quality of their commodities."); see also $\mathrm{Yu}$, supra note 71, at 318-19 (listing trademark infringement and other acts prohibited under the Anti-Unfair Competition Law).

82. Anti-Unfair Competition Law, supra note 70, at art. 21; see also Yu, supra note 70, at 328-29 (detailing the remedies in Article 21).

83. See AUCL Interpretation, supra note 76.

84. See AUCL Interpretation, supra note 76.

85. See Anti-Unfair Competition Law, supra note 70, at art. 33 ("This law shall go into effect as of December 1, 1993."); AUCL Interpretation, supra note 76, at pmbl.

86. AUCL Interpretation, supra note 76, at pmbl.

87. AUCL Interpretation, supra note 76, at art. 1-2; see also Aitefu Co. v. Beijing Ditan Hosp. (Sup. People's Ct. March 23, 2003) (China) ("To sum up, the specific name of a famous commodity shall be protected by law, and the owner of the commodity shall have the right to prevent others from using the specific name of its famous commodity without permission to conduct unfair competition act [sic].").

88. AUCL Interpretation, supra note 76, at art. 2 (listing the features that should not be considered to include: "(1) the commonly-used name, graphics or model of the commodities; (2) the name of the commodities that just directly specifies the quality, major raw materials, functions, utilities, weight, quantity or any other characteristic of the commodities; (3) the shape produced due to the nature of the commodities, the shape of the commodities that should be produced for the purpose of obtaining technical effects, as well 
refers only to a product with certain market popularity in China that is known by the relevant public. ${ }^{89}$ Lower courts must consider factors such as duration, territory, volume, and the target market, in determining whether a product has enjoyed market popularity. ${ }^{90}$

Through the AUCL Interpretation, the Supreme People's Court expands the "decoration of the famous or noted commodities" language of Article 5 of the Anti-Unfair Competition Law. ${ }^{91}$ The Court offers its interpretation to be "the pattern of business appliances, or the clothes of operating personnel ... [that] constitutes an overall business image with a unique style," and therefore affords legal protection under the Anti-Unfair Competition Law. ${ }^{92}$ This protects distinctive trade dress, or the look and feel or total appearance of a product or service. ${ }^{93}$

The Court also extends legal protection to a name belonging to an enterprise. The name can be a name of any domestic enterprise or a name of any foreign enterprise used in China for commercial purposes. ${ }^{94}$ Such names will be protected under the Anti-Unfair Competition Law. In addition, "a shop name in the name of enterprise" is also protected if the

as the shape that produces substantial value to the commodities; or (4) other name, package or ornament of the commodities that has no notable characteristic [sic].").

89. AUCL Interpretation, supra note 76, at art. 1.

90. AUCL Interpretation, supra note 76, at art. 1 ("The people's court shall take into account the time, region, volume and targets for selling such commodities, the duration, degree and scope for any promotion of such commodities, as well as the protection situation as well-known commodities, and make comprehensive judgments when affirming wellknown commodities.").

91. AUCL Interpretation, supra note 76, at art. 3.

92. AUCL Interpretation, supra note 76, at art. 3.

93. See Long, supra note 40, at 82 (noting that China enacted the Law Against Unfair Competition which offered protection to distinctive trade dress in 1993); Paul B. Birden, Jr., Trademark Protection in China: Trends and Directions, 18 LoY. L.A. INT'L \& CoMP. L.J. 431, 448 (1996) (mentioning trade dress protection under China's Anti-Unfair Competition Law). The interpretation provided by the Supreme People's Court on trade dress brings to mind Two Pesos, where the U.S. Supreme Court addressed the trade dress of a fast food, Mexican-themed restaurant. The trade dress in Two Pesos was described as:

a festive eating atmosphere having interior dining and patio areas decorated with artifacts, bright colors, paintings and murals. The patio includes interior and exterior areas with the interior patio capable of being sealed off from the outside patio by overhead garage doors. The stepped exterior of the building is a festive and vivid color scheme using top border paint and neon stripes. Bright awnings and umbrellas continue the theme.

Two Pesos, Inc. v. Taco Cabana, Inc., 505 U.S. 763, 765 (1992) (quoting Taco Cabana Int'l, Inc. v. Two Pesos, Inc., 932 F.2d 1113, 1117 (5th Cir. 1991)); see also Xuan-Thao Nguyen, Should It be a Free for All? The Challenge of Extending Trade Dress Protection to the Look and Feel of Websites in the Evolving Internet, 49 AM. U. L. REV. 1233, 1239-40 (2000) (discussing trade dress protection for look and feel of products and services).

94. AUCL Interpretation, supra note 76, at art. 6. 
shop name has "certain market popularity" and is recognized by the relevant public. ${ }^{95}$ Any unauthorized use of protected names will be deemed unfair competition. ${ }^{96}$

With respect to the name of an individual, the Court explains that if the name of a person is used in "the business operation of commodities," the name will similarly be entitled to protection under the Anti-Unfair Competition Law. ${ }^{97}$ Unauthorized use of a name in connection with products in a way that causes public confusion is prohibited. ${ }^{98}$

In summary, understanding China's trademark jurisprudence requires a search beyond China's Trademark Law. Names, whether belonging to an individual or an entity, are protected from unauthorized use by a third party who harms the reputation of the name by misleading or confusing the public into believing that products bearing the name come from the same origin. ${ }^{99}$ The source of legal protection for protected names is China's Anti-Unfair Competition Law, which provides coverage that is broader than China's Trademark Law. ${ }^{100}$ The China Supreme People's Court has a formative role in designing trademark jurisprudence, as seen in its extensive judicial directives interpreting China's Anti-Unfair Competition Law. ${ }^{101}$ In the absence of a stare decisis legal system, the Court skillfully incorporated fourteen years of judicial decisions to craft its AUCL interpretations. In some ways, not surprisingly, China's Anti-Unfair Competition Law shares some similarities to the United States' Lanham Act on Unfair Competition. Like Article 5 of China's Anti-Unfair Competition Law, Section 43(a) of the Lanham Act provides that registration of a term or name is not required; yet, unauthorized use of the term or name in connection with goods that causes consumer confusion is prohibited. $^{102}$

\section{China's Civil Law and Supreme People's Court}

The most important body of law for understanding China's trademark jurisprudence is the General Principles of the Civil Law of the People's

95. AUCL Interpretation, supra note 76 , at art. 6.

96. AUCL Interpretation, supra note 76, at art. 6.; Anti-Unfair Competition Law, supra note 70, at art. 5(3).

97. AUCL Interpretation, supra note 76, at art. 6.

98. Anti-Competition Law, supra note 70, at art. 5(3).

99. Anti-Competition Law, supra note 70, at art. 5(3).

100. Anti-Competition Law, supra note 70, at art. 5(3).

101. See AUCL Interpretation, supra note 76 (announcing the adoption of the Court's interpretation of the application of law in trials involving unfair competition).

102. False Designations of Origin, False Descriptions, and Dilution Forbidden,15 U.S.C. $\S 1125$ (a) (2006) (codification of Lanham Act § 43(a)). 
Republic of China. ${ }^{103}$ China's Civil Law was promulgated in 1986 and became effective January 1, 1987. ${ }^{104}$ This copious law protects the civil rights ${ }^{105}$ and interests of Chinese citizens and legal persons, ${ }^{106}$ and governs civil relations within the framework of a developing socialist country. ${ }^{107}$ Relevant articles in China's Civil Law relating to trademark jurisprudence deserve close attention. ${ }^{108}$

China's Civil Law provides a separate section entitled "Intellectual Property Rights," which recognizes that exclusive rights in patents, copyrights, and trademarks obtained by legal persons are entitled to protection. ${ }^{109}$ Pertinent to this paper, China's Civil Law mandates that the "rights to exclusive use of trademarks obtained by legal persons, individual businesses, and individual partnerships shall be protected by law."110 This

103. China's Civil Law, supra note 37.

104. China's Civil Law, supra note 37.

105. China's Civil Law includes inheritance, adoption, family, and intellectual property law, among others. China's Civil Law, supra note 37.

106. "Legal person" is defined in Articles 36 and 37:

Article 36: A legal person shall be an organization that has capacity for civil rights and capacity for civil conduct and independently enjoys civil rights and assumes civil obligations in accordance with the law. A legal person's capacity for civil rights and capacity for civil conduct shall begin when the legal person is established and shall end when the legal person terminates.

Article 37: A legal person shall have the following qualifications:

(1) establishment in accordance with the law;

(2) possession of the necessary property or funds;

(3) possession of its own name, organization and premises; and

(4) ability to independently bear civil liability.

China's Civil Law, supra note 37 at art. 36-37.

107. Chinas Civil Law, supra note 37 at art.1:

This Law is formulated in accordance with the Constitution and the actual situation in the country, drawing upon the practical experience in civil activities, for the purpose of protecting the lawful civil rights and interests of citizens and legal persons and correctly adjusting civil relations, so as to meet the needs of the developing socialist modernization.

108. See generally Kara L. Phillips \& Amy L. Sommers, A Tragedy of the Commons: Property Rights Issues in Shanghai Historic Residences, 28 PenN St. InT'L Rev. 137, 166 n.141 (2009) (noting that China's Civil Law discusses contractual and property rights "at Chapter 5 and contains four sections, addressing Property Ownership and Related Ownership Rights, Creditors Rights, Intellectual Property Rights and Personal Rights.”).

109. China's Civil Law, supra note 37, at art. 94-97.

110. See Chinas Civil Law supra note 37, at sec. 3 ("Article 94 Citizens and legal persons shall enjoy rights of authorship (copyrights) and shall be entitled to sign their names as authors, issue and publish their works and obtain remuneration in accordance with the law. Article 95 The patent rights lawfully obtained by citizens and legal persons shall be protected by law. Article 96 The rights to exclusive use of trademarks obtained by legal persons, individual businesses and individual partnerships shall be protected by law."). 
means if the exclusive right to use a trademark is infringed, the trademark registrant has the right to demand that "the infringement be stopped, its ill effects be eliminated and the damages be compensated" as prescribed in Article 118 of China's Civil Law. ${ }^{111}$ The court also eliminates ill effects by ordering the defendant to make a public apology in a newspaper or trade publication. $^{112}$

Not only do owners of trademarks enjoy legal protection under China's Civil Law, legal persons and individuals have the legal protection of "the right of name." Indeed, under China's Civil Law, Chinese citizens, legal persons, businesses, partnership, and enterprises all have "the right of name" and "the right to use and lawfully assign their own names." 113 Essentially, the legal protection afforded under China's Civil Law extends to unregistered trademarks or names that have not been registered under China's Trademark Law. Furthermore, Article 120 of China's Civil Law mandates that legal protection as it relates to the legal person's "right of personal name, portrait, reputation or honor" means that the individual or business entity has the right to "demand that the infringement be stopped," the individual's or business entity's "reputation be rehabilitated," and the "ill effects be eliminated." 114 Most importantly, the individual or business entity can demand for compensatory damages and "an apology" in addition to injunctive relief. ${ }^{115}$

In addition to Articles 118 and 120 providing injunctive relief, damages, costs and public apologies as remedies, China's Civil Law has another relevant provision relating to civil liability when rights such as trademark rights and the "right of name, reputation or honor" are infringed. Article 134 of China's Civil Law provides a set of "methods of bearing civil liability" 116 that courts can select and apply as appropriate remedies in

111. Chinas Civil Law, supra note 37, at art. 118.

112. See Fangfang Ceramics Manufactory v. Hengsheng Ceramics and Bldg. Materials Manufactory, (Higher People's Ct. of Fujian Province Dec. 30, 1998) (China) (applying art. 118 of China's Civil Law to order the defendant to stop its infringing conduct, pay for damages and publish an apology in a newspaper).

113. China's Civil Law, supra note 37, at art. 99.

114. Chinas Civil Law, supra note 37, at art. 120.

115. Chinas Civil Law, supra note 37, at art. 120.

116. Chinas Civil Law, supra note 37, at art. 134 ("The main methods of bearing civil liability shall be: (1) cessation of infringements; (2) removal of obstacles; (3) elimination of dangers; (4) return of property; (5) restoration of original condition; (6) repair, reworking or replacement; (7) compensation for losses; (8) payment of breach of contract damages; (9) elimination of ill effects and rehabilitation of reputation; and (10) extension of apology. The above methods of bearing civil liability may be applied exclusively or concurrently. When hearing civil cases, a people's court, in addition to applying the above stipulations, may serve admonitions, order the offender to sign a pledge of repentance, and confiscate the property used in carrying out illegal activities and the illegal income obtained therefrom."). 
cases where principles of civil law have been violated by the defendant. Among the ten methods, "elimination of ill effects and rehabilitation of reputation" and "apology" are listed in Article 134 of China's Civil Law. ${ }^{117}$

Significantly, China Supreme People's Court dictates through its judicial directives that the lower people's courts follow Article 134 of China's Civil Law in issuing remedies for the prevailing plaintiff. ${ }^{118}$ In addition to the pertinent remedies provided in China's Trademark Law, the lower people's courts may order the infringer to "stop[] the infringement, remov[e] obstacles, eliminate[e] hazards, [and] compensate[e] losses." 119 Recent decisions published by Chinese courts have applied Articles 118, 120 and 134 of China's Civil Law in issuing orders against defendants who have used trademarks belonging to others and harmed the reputation of trademark owners. ${ }^{120}$

Combining the three sources of law-Trademark Law, Anti-Unfair Competition Law and Civil Law-with the judicial directives, presents a complete view of China's trademark jurisprudence. China extends trademark protection to both registered and unregistered names. If the unregistered names have been used by the plaintiffs in commerce to build their reputation over time, they are eligible for protection. China seems to understand that trademarks and names are an embodiment of reputation and the unauthorized use that may mislead the public is harmful to both the plaintiff and the public. China provides similar reputational protection for trade dress, the packaging or look and feel of a product or service.

Protection for trademark reputation as dictated by the three laws and judicial directives can be seen in the written decisions published by lower people's courts. Judicial opinions, though not binding, ${ }^{121}$ illustrate the development of trademark jurisprudence across China. Such decisions are

117. Chinas Civil Law, supra note 37, at art. 134

118. See Trademark Law Interpretation, supra note 33, at art. 21: ("In hearing a case of dispute over the exclusive right to use a registered trademark, the people's court may, according to the provisions of Article 134 of the General Principles of the Civil Law and Article 53 of the Trademark Law and the specific circumstances of the case, rule that the infringer bear the civil liabilities for stopping the infringement, removing the obstacles, eliminating dangers, compensating damages and eliminating ill-effects. It may, in addition, impose a fine, confiscate the infringing goods, representations of the counterfeited trademark and the materials, implements and/or equipment for making the infringing goods. The amount of fine may be determined in light of the relevant provisions of the Implementing Regulations of the Trademark Law.").

119. See Trademark Law Interpretation, supra note 33, at art. 21

120. See infra Parts II-III (exploring different judicial decisions regarding trademark infringement).

121. Chua, supra note 52, at 136 ("Although there is no system of binding case precedent in China, such written decisions can at least provide guidance to the public and legal practitioners."). 
important, as they relate to protecting an individual person or entity's reputation, compensating the injured person or entity, enjoining the misleading of the public caused by the defendant's unauthorized use of a name and restoring public order. The public apology also plays a corrective measure in the remedy to make the injured individual or entity and the public whole again.

\section{JUDICIAL DECISIONS ON TRADEMARK REPUTATION}

An analysis of the official Chinese judicial decisions that are both published and translated into English indicates that Chinese courts protect registered trademarks or names of legal persons against unauthorized use, Additionally, these decisions apply Articles 118, 120, or Article 134 of China's Civil Law to eliminate ill effects, and order public apology when the defendant willfully engages in conduct that harms the reputation of the plaintiff's name or registered trademark. Public apology is generally in addition to injunction, damages and litigation costs. Below are the decisions.

\section{A. Tianjin Goubuli Baozi Catering (Group) Company v. Harbin Tianlongge Hotel and Gao Yuan}

The plaintiff in this case obtained a trademark registration for the name "Goubuli" for baozi products in July of 1980. ${ }^{122}$ Baozi is a type of Chinese steamed bun with meat filling. ${ }^{123}$ The plaintiff brought a trademark infringement action against defendants, Harbin Tianlongge Hotel and Gao Yuan, for using the "Goubuli" trademark without permission in 1991. ${ }^{124}$ The defendants argued that their use of the "Goubuli" name was merely for identification purposes. Specifically, they asserted that defendant Gao Yuan was the direct descendant of Gao Guiyou, the originator of the "Goubuli" baozi, and had entered into an agreement with defendant Harbin Tianlongge Hotel to use the name "Goubuli" in the plaque hanging at the hotel entrance where the defendant Gao Yuan worked as a pastry chef. ${ }^{125}$ The plaque stated, "Gao Yaolin, the Fourth Generation Offspring of and Gao Yuan, the Fifth Generation

122. Tianjin Goubuli Baozi Catering (Group) Co. v. Harbin Tianlongge Hotel and Gao Yuan, (Higher People's Ct. of Heilongjian Province Dec. 28, 1994) (China).

123. Ye Jun, Best of the Buns, China DAILY (May 21, 2004, 3:34 PM), available at http://www.chinadaily.com.cn/english/doc/2004-05/21/content_332721.htm.

124. Tianjin, (Higher People's Ct. of Heilongjian Province Dec. 28, 1994) (China).

125. Id. 
Offspring of Authentic Tianjin Goubuli Baozi." ${ }^{126}$ In 1993, both the Harbin Xiangfang District People's Court and the Harbin Intermediate People's Court found no trademark infringement and ruled in favor of the defendants. ${ }^{127}$ The plaintiff then appealed to the Higher People's Court of Heilongjian Province.

On December 28, 1994, the Higher People's Court reversed the lower court's decision and found that the "Goubuli" trademark was a valid trademark registered by the plaintiff and that under trademark law the plaintiff had the exclusive right to use the trademark and enjoyed the protection of the law. ${ }^{128}$ The Court noted that even though Gao Yuan called himself a descendant of the original creator of Goubuli baozi, he had neither the right to use the trademark Goubuli nor the authority to enter into an agreement with the defendant hotel for its use of the trademark. The Court concluded that the defendants' hanging of the plaque at the hotel door entrance was for the purpose of operating the hotel, and therefore defendants were in violation of the plaintiff's exclusive right to use its trademark. The defendants' use was not merely to identify the offspring of the original creator of Goubuli baozi. ${ }^{129}$

The Higher People's Court then applied Article 134(1), (7) and (10) ${ }^{130}$ and ordered the defendants to stop the infringing conduct, destroy the plaque and pay 44,800 yuan to the plaintiff within ten days of the judgment. The Court also awarded the plaintiff 7380 yuan for litigation costs. In addition, the Court ordered the defendants to "publish a statement of apology" in a newspapers of similar rank "at or above the city level in Harbin." "131 The Court proclaimed that the content of the apology "shall be subject to examination and approval of this Court" and that the defendants must bear the relevant expenses. ${ }^{132}$

\section{B. China Pharmaceutical University v. Furui Technology Co., Ltd.}

China Pharmaceutical University ("CPU" or "University") is a wellknown public university in China, specifically in the field of medicine. ${ }^{133}$

\footnotetext{
126. Id.

127. Id.

128. Id.

129. Id.

130. China's Civil Law, supra note 37, at art. 134 (methods of bearing civil liability include "(1) cessation of infringements, ... (7) compensation for losses; .. . (10) extension of apology").

131. Tianjin, (Higher People's Ct. of Heilongjian Province Dec. 28, 1994) (China).

132. Id.

133. China Pharm. Univ. v. Furui Tech. Co., (Higher People's Ct. of Jiangsu Province Jan. 31, 2005) (China).
} 
Along with affiliated enterprises, CPU has transformed many of its scientific research achievements into producing medical instruments and medicines, which it has brought to the marketplace. CPU does not own a registered trademark, but enjoys a good market reputation through its affiliated enterprises and has become a "symbol of market competition in the pharmaceutical industry."134

The defendant, Furui Technology, is in the business of making nutritional supplements. ${ }^{135}$ On March 2, 2004, the defendant began to sell baby nutritional supplements under the name "China Pharmaceutical University," with the name printed on the packaging boxes and advertisement materials. The defendant insisted that its use of the name "China Pharmaceutical University" was justifiable because in 2003 it had rented a room from the Physical Education Department of China Pharmaceutical University, and the name was part of the contact address. ${ }^{136}$ CPU brought an action of unfair competition against the defendant.

The Nanjing Intermediate People's Court issued its decision in late 2004. ${ }^{137}$ The Court applied China's Anti-Unfair Competition Law and found that under Article 2 of that law, CPU has the capability of a business operator through its affiliation with other enterprises, and therefore it can bring a suit against the defendant for unfair competition. The Intermediate People's Court then applied Article 5 of China's Anti-Unfair Competition Law, which prohibits businesses from using "any other's enterprise name or personal name to mislead people into believing that the commodities are produced by the other enterprise or person." 138 The Court explained that the original legislative intent was to forbid businesses "from taking advantage of the reputation of any other to sell its own products, which will injure its counterparts." 139 The Court recognized that although the name "China Pharmaceutical University" was not an enterprise name, the name had been used to make "its medicines competitive" through its business affiliations with various enterprises, ${ }^{140}$ and therefore the name "China Pharmaceutical University" was protected from "illegal use" that would impair its reputation. ${ }^{141}$

The Intermediate People's Court ultimately concluded that the

134. Id.

135. Id.

136. $I d$.

137. Id. (the lower court, the Intermediate People's Court of Nanjing, rendered its decision on December 13, 2004).

138. Id. (quoting Article 5 of China's Anti-Unfair Competition Law).

139. Id.

140. Id.

141. Id. 
defendant violated China's Anti Unfair Competition Law. In reaching its conclusion, the Court first focused on the tenant lease agreement between the Physical Education Department of China Pharmaceutical University and the defendant, Furui Technology. The lease was for a term of three years, at the annual rate of 7,000 yuan. The lease agreement expressly prohibited the defendant from engaging in any commercial activity in the name of China Pharmaceutical University and stipulated that its commercial activities should have no connection with the University. The Intermediate People's Court noted that the defendant printed the words "Honorable Production of Furui Technology, Eastern Campus of China Pharmaceutical University, Nanjing Municipality, P.R. China," "Jiangsu Furui Technology Ltd. Co., East of China Pharmaceutical University, Nanjing Municipality, P.R. China," and "Contact address: Box 181 of China Pharmaceutical University, Nanjing Municipality, P.R. China" on its packages and marketing materials. ${ }^{142}$ With such conspicuous use of the University's name, the defendant "infringed on the right" of the name, "usurped the commercial reputation of China Pharmaceutical University," "caused the confusion to the general public," and "cheated the consumers" as to its affiliation with CPU. ${ }^{143}$

The Intermediate People's Court then looked to Article 134 of China's Civil Law in issuing its ruling against the defendant. The Court ordered an injunction, and the defendant was directed to cease all infringing use of the University's name and destroy all infringing packages and marketing materials. The defendant was instructed to pay the University 100,000 yuan for economic losses along with litigation costs. The Court also compelled the defendant to make a public apology within fifteen days of the judgment in the Yangzi Evening News "so as to eliminate bad effects caused by" the defendant's unauthorized use of the University's name. ${ }^{144}$ The Court admonished the defendant that if it did not promptly make the public apology, "the main contents of this judgment would be published, and the fees incurred therefrom should be borne" by the defendant. ${ }^{145}$ The Court entered its decision on December 13, 2004. The defendant appealed to the Higher People's Court of Jiangsu Province. On January 31, 2005, the Higher People's Court of Jiangsu Province affirmed the lower court's decision on its application of law, finding of fact and civil liability judgment. $^{146}$

142. $I d$.

143. Id.

144. Id.

145. Id.

146. Id. 


\section{Shenhua Football Club v. Teleitong Trade Ltd Corp.}

The plaintiff Shenhua Football Club is a nationally-known football club in China. ${ }^{147}$ On March 21, 1999, the plaintiff moved its headquarters office from Quyang Road, Shanghai to Hongkou Football Stadium on Dongjiangwan Road, Shanghai. The plaintiff accused the defendant Teleitong of using the "Shenhua" name in its commercial advertisements for furniture products published in Xinmin Sports News on March 22, March 25 and April 2 of 1999 . In the commercial advertisements, the defendant included the following sentence after it introduced Teleitong's furniture line products: "Shenhua has moved to a new home, how about you?"148

The People's Court of Jingan District in Shanghai held that under China's Civil Law "[1]egal persons, individual businesses, and individual partnerships shall enjoy the right of name." ${ }^{149}$ Furthermore, enterprises such as "legal persons, individual businesses and individual partnerships" have "the right to use and lawfully assign their own names." 150 The Jingan District Court followed the judicial directive issued by the Supreme People's Court on China's Civil Law, which instructed that "the usurpation or false representation of another person's name or title that has resulted in damage shall be regarded as infringement on the right of name or title."151 Accordingly, the Jingan District Court found that "Shenhua" was the name of the plaintiff Shenhua Football Club, and therefore the plaintiff was entitled to "the right of name of legal person, and to its use ... [and] any usurpation or false representation by others shall be prohibited."152 In addition, the Jingan District Court recognized the fame of "Shenhua" meant that the name had become "a symbol of honor and has the capability to exert influence on the public under certain circumstances" and that "[i]n a society of commodity economy, such name is an intangible asset for the owner for its ability to bring in commercial profit." 153 Accordingly, any unauthorized use of the name was an act of infringement. The defendant's commercial advertisements used the "Shenhua" name without authorization, and therefore the defendant must "bear civil liability."154

147. Shenhua Football Club v. Teleitong Trade Ltd. Corp., LawInfochina (Shanghai Second Interm. People's Ct. Sept. 11, 2000) (China).

148. Id.

149. Id.

150. $I d$.

151. Id.

152. Id.

153. $I d$.

154. Id. 
The Jingan District Court then applied Article 120 of China's Civil Law, which provides that if a citizen or legal person's "right of personal name... reputation or honor is infringed upon, he shall have the right to demand that the infringement be stopped, his reputation rehabilitated, the ill effects eliminated and an apology made...."155 Under this law, the Jingan District Court could issue an injunction against the defendant and restore the plaintiff's reputation by ordering the defendant to make a public apology. Article 120 of China's Civil Law also provides compensatory damages to make the plaintiff whole again. Here, the defendant was ordered to pay the plaintiff 50,000 yuan for its economic losses and 7110 yuan for litigation costs. ${ }^{156}$ In addition, the Jingan District Court directed defendant Teleitong to publish a notice in the Xinmin Sports News apologizing to the plaintiff within ten days after the judgment. The defendant appealed to the Shanghai Second Intermediate People's Court.

On September 11, 2000, the Shanghai Second Intermediate People's Court held that the Jingan District Court's factual findings were correct. ${ }^{157}$ The Court recognized that under the law, the "legal person is entitled to use its name and to prohibit any other person from using it illegally." ${ }^{158}$ Here, defendant Teleitong used the name of Shenhua Club in its commercial advertisements without consent and such use constituted "infringement upon the right of name of Shenhua Club." ${ }^{\text {159 }}$ The Court rejected the defendant's argument that its use was not malicious and could not be considered infringement of the Shenhua name. ${ }^{160}$ Affirming the lower court's ruling on remedies, the Intermediate Court also ordered that litigation costs incurred at both district court and appellate court levels "shall be borne" by defendant Teleitong. ${ }^{161}$

\section{Fangfang Ceramics Manufactory v. Hengsheng Ceramics and Building Materials Manufactory}

On February 28, 1993, the plaintiff, Fangfang Manufactory, obtained a trademark registration for "Hengsheng" in connection with ceramic tile products. $^{162}$ The defendant, Hengsheng Ceramics, used the name

155. Id.

156. $I d$.

157. $I d$.

158. Id.

159. Id.

160. Id.

161. Id.

162. Fangfang Ceramics Manufactory v. Hengsheng Ceramics and Bldg. Materials Manufactory, (Higher People's Ct. of Fujian Province Dec. 12, 1998) (China). 
"Hengsheng" on its ceramic tiles without the plaintiff's authorization. The plaintiff brought a trademark infringement suit against the defendant alleging that the defendant had intentionally misled the consumer as to the source of the tiles. The defendant asserted that "Hengsheng" was part of its company name as approved by an administrative agency for enterprises. ${ }^{163}$ The Intermediate People's Court of Quanzhou City found that, although the defendant had the right to use its company name, it had no right to use the name "Hengsheng" on ceramic tile boxes because the name had already been registered by the plaintiff as a trademark for its ceramic tile products. $^{164}$ The plaintiff, as owner of the registered trademark "Hengsheng," had the exclusive right to use the trademark. The defendant's unauthorized use constituted infringement. The Quanzhou Court applied Article 118 of China's Civil Law to determine the defendant's liability. ${ }^{165}$ The defendant was ordered to stop its infringing use of the registered trademark, pay economic losses of 50,000 yuan to the plaintiff and make an apology. ${ }^{166}$

On appeal, the Higher People's Court of Fujian Province rejected the defendant's argument that it merely used its company name; the defendant, in fact, used the registered trademark that belonged to the plaintiff. The Higher Court affirmed the lower court's order as to injunction, damages, and a public apology. ${ }^{167}$ The Higher Court also instructed the defendant to destroy the infringing tile boxes. ${ }^{168}$

In summary, the above four cases illustrate the dynamic development of trademark jurisprudence wherein courts-applying the three laws - recognize property rights to trademarks and names, and therefore issue injunctions directing the infringer to cease the infringing conduct. The injunction also prevents the spread of any unfair competition conduct

\footnotetext{
163. Id.

164. Id.

165. Id.

166. Id.

167. Id.

168. Id.; see also Starbucks Corp. \& Shanghai President Coffee Corp. v. Shanghai Starbucks Cafe Co., Ltd. \& Shanghai Starbucks Cafe Co., Ltd., Nanjing Road Branch (Higher People's Ct. of Shanghai Municipality Dec. 20, 2006) (China) (affirming the lower court's injunction, damages, costs, and public apology order against the defendant for its unauthorized and malicious use of Starbucks trademark); Beijing Pudun Clothes Mfg. Co., Ltd. v. Beijing Xianzi Clothing Co., Ltd. (The Second Interm. People's Ct. of Beijing Municipality Dec. 11, 2000) (China) (ordering the defendant to make a public apology for its deliberate infringement); Aiguefou Co. v. Nanjing No. 1 Pesticide Factory (Interm. People's Ct. of Nanjing Dec. 30, 1998) (China) (ordering the defendant to immediately desist from infringing upon the plaintiff's trademark right, compensate the plaintiff for economic losses, pay legal costs and auditing fee related to the litigation, and make an apology to the plaintiff in Nanjing Daily).
} 
committed by the infringer. To compensate for the damages incurred by the complainant stemming from the infringing conduct, courts apply liability rules to order the infringer to pay. Courts also include in the damages other costs, such as attorney's fees and expenses related to evidence collection. Injunctions and damages, however, are not the only remedies. Considering harm to trademark reputation is an injury to both the complainant and the public, and thus in cases where the defendant's infringing conduct was intentional or malicious, the court often instructs the infringer to make a public apology in addition to injunction and damages. The wrongdoer must publish the apology, the content of which is subject to the court's approval, in a newspaper selected by the court. ${ }^{169}$

Indeed, in the above four cases, the defendants were fully aware of the reputations associated with the plaintiffs' trademarks or names. The defendants deliberately ignored the plaintiffs' rights and exploited the commercial value in the trademarks or names by usurping that value. The defendants intentionally misled the public as to origin. Under apologetic justice, the courts address the harm by ordering public apologies upon finding malicious intent, in addition to the other remedies. On the other hand, when the defendant's infringing conduct is not malicious, the courts generally do not issue an order for public apology. ${ }^{170}$ Instead, the courts will only order some combination of an injunction, monetary damages and litigation costs.

\section{THE CONTENT OF PUBLIC APOLOGIES}

What is the content of a public apology ordered by Chinese courts against defendants in trademark infringement and unfair competition cases? A review of Chinese newspapers available online provides a window into the content of public apologies in trademark reputation cases. Consider the following apologies published in Chinese newspapers as illustrative examples: $:^{171}$

169. For another set of cases summary, see Top 10 IPR Cases in 2004, CHINA DAILY, available at http://www.chinadaily.com.cn/english/doc/2004-12/18/content_401345.htm (last updated Dec. 18, 2004, 9:38 AM).

170. See generally Beijing Delifrance Food Co., Ltd. v. Beijing Sun City Shopping Mall (Interm. People's Ct. of Beijng Municipality January 10, 1991) (China) (issuing injunction against the defendant and ordering the defendant to pay compensatory damages, attorney's fees, and investigation costs to the plaintiff).

171. Ms. Xu Fei and Ms. Kang Na, who both passed the Chinese Bar Exam before they enrolled at the SMU Dedman School of Law LLM program in 2010-11, assisted the author in the research for public apologies in intellectual property cases. Based on their research results, here is a list of newspapers where public apologies were published: Beijing Evening; China Theater News; Econ. Daily; Gangzhou Evening Newspaper; Motor Cycle 
I, Yu Haijun (ID No. : 330825197612254618), hereby certify that I used the trademark "Su Jia Ai Hua" without the permission of Su Aihu, who is the trademark registrant, and I am therefore expressing my sincere apology to the trademark registrant, and ensure that I will not use the trademark "Su Jia Ai Hua" without permission again.

I, Yu Lijun (ID No. : $33082519690718451 X$ ), hereby certify that I used the trademark "Su Jia Ai Hua" without the permission of Su Aihu, who is the trademark registrant, and I am therefore expressing my sincere apology to the trademark registrant, and ensure that I will not use the trademark "Su Jia Ai Hua" without permission again.

I, Zhong Zhiping (ID No. : 332527196911102626), hereby certify that I used the trademark "Su Jia Ai Hua" without the permission of Su Aihu, who is the trademark registrant, and I am therefore expressing my sincere apology to the trademark registrant, and ensure that I will not use the trademark "Su Jia Ai Hua" without permission again.

I, Yu Lijun (ID No. : 330702196809122622), hereby certify that I used the trademark "Su Jia Ai Hua" without the permission of Su Aihu, who is the trademark registrant, and I am therefore expressing my sincere apology to the trademark registrant, and ensure that I will not use the trademark "Su Jia Ai Hua" without permission again.

The four apologies above are made by individual infringers of the trademark "Su Jia Ai Hua." The apologies were published in the Zhejiang Legal Daily on March 26, 2010. ${ }^{172}$ All four infringers admitted that they used the trademark owned by the trademark registrant without authorization. They expressed their apologies to the trademark registrant, $\mathrm{Su}$ Aihu, in the public forum. The infringers each promised that they would not use the trademark without permission in the future.

The next apology is lengthier, as it includes the ruling from Tianjing Supreme People's Court against the defendant Tianjin Gang Tian Group for infringing the trademark "Yamaha."

According to the civil judgment from the Tianjin Supreme Court, we state as follows:

While reporting the 2009 and 2010 "National Catalog of Manufacturers and Products for Automobile, Civil Refitted Car and Motorcycle", we used "Linhai-Yamaha" as the engines' trademark, on the types of GT125T, GT125T-A, GT125T-B, and GT505T-A Gang Tian Motorcycles, which has been determined

Trade Papers; South Daily; Xinhua Daily; Zhejiang Legal Daily. They also translated the public apologies for the author. All of these translations are on file with the author.

172. Apology Statement, ZheJiAng Legal DAILY, Mar. 26, 2010, available at http://zjfzb.zjol.com.cn/html/2010-03/26/content_3_1.html. 
to be infringement on the trademark of Yamaha Motor Co., Ltd in the above-mentioned judgment.

The GT50T-A type Gang Tian motorcycles, also produced by our subordinate enterprise Tianjin Gang Tian Engine Co., Ltd., were attached with the mark "Engine licensed by Yamaha" at the front and rear. This expression has also been determined as infringement on the trademark of Yamaha Motor Co., Ltd in the above-mentioned paper of judgment.

We hereby apologize to Yamaha Motor Co., Ltd. for these trademark infringements. And, we have already modified the contents related to the "Linhai-Yamaha" engines in "National Catalog of Manufacturers and Products for Automobile, Civil Refitted Car and Motorcycle." Furthermore, we guarantee that we will not commit those or similar infringing acts in the future.

The defendants, the Tianjin Gang Tian Group, made the above public apology as published in a motorcycle trade publication in April of 2003. ${ }^{173}$ The apology shows that the defendants admitted they had engaged in infringing conduct in violation of the plaintiff's trademark rights. Specifically, the defendants used the plaintiff's Yamaha trademark in catalogs without permission. By stamping the phrase "Engine licensed by Yamaha" on their products, the defendants falsely advertised and sold their own products as Yamahas. The defendants misled the public by falsely asserting that they had received a license to distribute engine products from the plaintiff. The defendants apologized for their deeds and promised that they would not engage in similar trademark infringing conduct.

\section{TRADEMARK HARM AND APOLOGETIC JUSTICE}

Judge Learned Hand perceptively observed that the unauthorized use of a trademark or name causes harm to trademark reputation and recognized that such harms constitute an injury. The United States and China each have different approaches to remedying harm to trademark reputation. China does not follow the U.S. approach to remedies in cases of trademark reputation harm. Public apology is one of the remedies in cases where an individual or legal person's name is maliciously or willfully infringed. This apologetic justice is absent in U.S. law on trademark reputation harm.

173. The Chinese and English versions of the apology are on file with the author. Another trademark infringement case was brought by Yamaha, and in 2007, the Supreme People's Court in Beijing ordered the defendant to cease the infringing conduct, pay $\$ 8.3$ million yuan in damages and make a public apology. Olivia Chung, A Trademark Milestone for Yamaha in China, AsiA TIMES OnLINE, June 29, 2007, http://www.atimes.com/atimes/China_Business/IF29Cb02.html. 
In the United States, the plaintiff can seek legal protection for trademark reputation under the Lanham Act, the federal unfair competition law. ${ }^{174}$ The plaintiff does not need to own a registered trademark, name or symbol. ${ }^{175}$ The Lanham Act prohibits any person from using in commerce any word, name, symbol, false designation of origin, or misleading description of fact that is likely to cause confusion, mistake, or deception as to the affiliation or association of the person with another person. ${ }^{176}$ The federal unfair competition statute also prohibits the use of a word, name, or symbol belonging to another person in commercial advertising. ${ }^{177}$

Typically, if the plaintiff prevails under the Lanham Act, it may ask the court for injunctive relief. ${ }^{178}$ Unlike in China, where injunctive relief is routinely granted after the plaintiff's name is found to be infringed, ${ }^{179}$ in the United States the prevailing plaintiff must proceed to the next step of

174. See Fabrication Enters., Inc. v. Hygenic Corp., 64 F.3d 53, 57 (2d Cir. 1995) (" $[\mathrm{T}]$ he purpose of the Lanham Act... is to secure 'the public's interest in protection against deceit as to the sources of its purchases, [and] the businessman's right to enjoy business earned through investment in the good will and reputation attached to a trade name."') (alteration in original) (quotation omitted); David S. Ardia, Reputation in a Networked World: Revisiting the Social Foundations of Defamation Law, 45 HARV. C.R.C.L. L. REV. 261, 277 n.92 (2010) (noting that the Lanham Act protects and regulates reputation); Laura A. Heymann, The Law of Reputation and the Interest of the Audience, 52 B.C. L. REv. 1341, 1385-1400 (2011) (analyzing trademark reputation cases under the Lanham Act).

175. Aaron Clark, Not All Edits Are Created Equal: The Edited Movie Industry's Impact on Moral Rights and Derivative Works Doctrine, 22 SANTA Clara COMPUTER \& High Tec. L.J. 51, 54 (2005) ("The Lanham Act § 43(a) embodies federal unfair competition law and is aimed at preventing and redressing 'misrepresentations that may injure plaintiff's business or personal reputation, even where no trademark is concerned."') (quoting Gilliam v. Am. Broad. Cos., 538 F.2d 14, 24 (2d Cir. 1976)).

176. 15 U.S.C. $§ 1125$ (a) (2006) (Section 43 (a) of the Lanham Act). In 1946, Congress passed the Lanham Act "to protect the public from deceit, to foster fair competition, and to secure to the business community the advantages of reputation and good will by preventing their diversion from those who have created them to those who have not." S. REP. NO. 791333, at 4 (1946), reprinted in 1946 U.S.C.C.A.N. 1274, 1277; Mobil Oil Corp. v. Pegasus Petroleum Corp., 818 F.2d 254, 259 (2d Cir. 1987) ("The Lanham Act extends trademark protection to related goods in order to guard against numerous evils in addition to restraints on the possible expansion of the senior user's market, including consumer confusion, tarnishment of the senior user's reputation, and unjust enrichment of the infringer."); see also Irina D. Manta, Privatizing Trademarks, 51 ARIZ. L. REV. 381, 390-92 (2009) (reviewing the history of the Lanham Act).

177. 15 U.S.C. $\S 1125(\mathrm{a})(2006)$.

178. Mark A. Lemley \& Mark McKenna, Irrelevant Confusion, 62 STAN. L. Rev. 413, 444 n.122 (2010) (asserting that injunctions are an appropriate remedy in cases where consumer confusion occurs as to the source of goods or services).

179. See Xuan-Thao Nguyen, The China We Hardly Know: Revealing the New China's Intellectual Property Regime, 55 ST. LouIS U. L.J. 773, 798-806 (2011) (discussing intellectual property cases and remedies in China). 
establishing the four factor test in order to obtain permanent injunctive relief. ${ }^{180}$ This assumes that the plaintiff has already gone to trial and succeeded at the infringement phase. ${ }^{181}$ Currently, ninety-eight percent of civil cases filed in the United States do not advance to trial; they are either settled or disposed of before trial. That means only two percent of civil cases reach the trial phase in hope of a permanent injunction and damages. ${ }^{182}$ Likewise, in 2007, over ninety-five percent of all trademark cases settled or terminated before trial and only two percent of trademark cases went to trial. ${ }^{183}$

Unlike in China, where the plaintiff routinely receives damages upon a finding of infringing use, ${ }^{184}$ damage awards in the United States are not awarded as a matter of right; they are only available if the plaintiff can

180. See PBM Prods., LLC v. Mead Johnson \& Co., 639 F.3d 111, 126 (4th Cir. 2011) (explaining that before an injunction may be issued, "the party seeking the injunction must demonstrate that (1) it has suffered an irreparable injury; (2) remedies available at law are inadequate; (3) the balance of the hardships favors the party seeking the injunction; and (4) the public interest would not be disserved by the injunction."). This four-factor test derives from a patent case by the Supreme Court, eBay Inc. v. MercExchange, L.L.C., 547 U.S. 388 (2006).

181. Even in trademark cases where the plaintiff seeks a preliminary injunction and does not go to trial, courts hold that there is no presumption of irreparable harm upon a finding of a likelihood of success on the merits. The plaintiff still must establish the four-factor test established in eBay v. MercExchange in order to obtain preliminary injunction. Voice of the Arab World, Inc. v. MDTV Med. News Now, Inc., 645 F.3d 26, 34 (1st Cir. 2011) (vacating the district court's preliminary injunction ruling and holding that "a request to preliminarily enjoin alleged trademark infringement is subject to traditional equitable principles, as set forth by the Supreme Court in eBay ...."); see also Salinger v. Colting, 607 F.3d 68, 77 (2d Cir. 2010) (holding that "eBay applies with equal force (a) to preliminary injunctions (b) that are issued for alleged copyright infringement").

182. Patricia Lee Refo, Opening Statement: The Vanishing Trial, 30 No.2 Litigation ONLINE 1, 2 (2004), available at http://www.swlaw.com/assets/pdf/publications/1999/12/12/ RefoVanishingTrial.pdf ("[F]ederal courts actually tried fewer cases in 2002 than they did in 1962, despite a fivefold increase in the number of civil filings" and only $1.8 \%$ of federal civil cases were disposed of by trial in 2002 compared to $11.5 \%$ in 1962) (emphasis omitted).

183. Gauri Prakash-Canjels \& Kristen Hamilton, Basis of Damage Awards in Trademark Cases, 44 Les Nouvelles 125, 125 (June 2009); Jerome Gilson \& Anne Gilson LaLonde, The Lanham Act: Time for a Face-Lift?, 92 Trademark ReP. 1013, 1019 (2002); Gauri Prakash-Canjels \& Kristen Hamilton, Basis of Damage Awards in Trademark Cases, 44 Les Nouvelles 125, 125 (June 2009) ("A majority of trademark cases are terminated before any court action occurs (33 percent in 2007) and another 54 percent of these cases are disposed off [sic] Pre-Trial. Only about 2 percent of trademark cases went to trial in 2007.").

184. If actual damages cannot be established in trademark infringement cases, the plaintiff can seek statutory damages up to 500,000 yuan. See China's Trademark Law, supra note 35, at art. 56 ("If it is difficult to determine the profits which the infringer has earned through infringement or the losses which the infringee has suffered as referred in the preceding paragraph, the people's court shall make a sentence of compensation under the amount of 500,000 Yuan RMB in accordance with the seriousness of infringing acts."). 
prove at trial with reasonable certainty that he or she has indeed suffered losses due to the defendant's particular use of the infringing mark in connection with specific products. ${ }^{185}$ In addition, courts will only award attorney's fees and litigation costs to the prevailing plaintiff at trial if the defendant deliberately or willfully infringed the trademark. ${ }^{186}$ In summary, under the Lanham Act, injunctive relief and damages are difficult and costly to obtain in practice. ${ }^{187}$

The uncertainty of obtaining an injunction and damages at trial, coupled with the high cost of litigation and the fractional number of cases advanced to trial, represent the current state of trademark cases in the United States. The reality, then, is that trademark cases may yield inconsistent judge-made trademark law. ${ }^{188}$ In a way, U.S. trademark law is a nice looking statute that is not effective in reality. ${ }^{189}$ Why should an

185. A plaintiff must demonstrate that the injury is proximately caused by the defendant's use of the trademark. See Phoenix of Broward, Inc. v. McDonald's Corp., 489 F.3d 1156, 1167 (11th Cir. 2007) (applying the test that "whether the injury alleged is the type of injury that the Lanham Act was designed to redress - harm to the plaintiff's 'ability to compete' in the marketplace and erosion of the plaintiff's 'good will and reputation' that has been directly and proximately caused by the defendant's false advertising.").

186. See 15 U.S.C. § 1117(a) (2012); Super Duper, Inc. v. Mattel, Inc., 382 F. App’x. 308138 (4th Cir. 2010) (affirming that the district court did not err in determining that the trademark infringement was an "exceptional case" and thus rendering the award of attorneys' fees appropriate).

187. The difficulty can be seen in Optimum Techs., Inc. v. Henkel Consumer Adhesives, Inc., where the district court declared a mistrial after the jury was unable to reach a verdict on trademark and unfair competition claims. 496 F.3d 1231, 1251 (11th Cir. 2007). The district court then ruled that the plaintiff had failed to establish a connection between the defendant's use of the trademark at issue and the expert's damages figure of \$7.6 million. Id. That means there was " "no legally sufficient evidentiary basis for a reasonable jury to find for" "the plaintiff on the issue of damages. Id. (quoting the district court). The district court awarded judgment as a matter of law to the defendant on the plaintiff's infringement and unfair competition claims. Id. The appellate court affirmed the district court's decision. Id.; see also Competition Specialties, Inc. v. Competition Specialties, Inc., 87 F. App'x. 38, 40 (9th Cir. 2004) (holding, after a four-day jury trial, that the defendant had infringed plaintiff's trademark, but that no damages were proximately caused by the infringement).

188. Gilson \& LaLonde, supra note 183, at 1019 ("No one knows whether the same trademark case would be decided differently from one circuit to another based on the different approaches. There are simply no empirical data, nor are there likely to be. Well over ninety-five percent of all trademark cases settle along the way, leaving just a tiny percentage that go to trial and a decision.").

189. Most illuminating example of the current state of trademark law is the story recounted by Gilson \& LaLonde:

At the TTAB's [Trademark Trials and Appeals Board's] twenty-fifth anniversary dinner, then-Chairman Saul Lefkowitz held up a shiny coin and asked the audience, "Do you know what this is?" He paused for dramatic effect. No one answered. He flipped it high in the air, caught it, and said, "This is how we decide likelihood of confusion." 
individual or business pay high attorney's fees and litigation costs to receive unsatisfactory results? The plaintiff may want more than just an injunction and monetary damages, even though these two types of remedies have become increasingly difficult to obtain. ${ }^{190}$ The plaintiff wants more, but what more means is not prescribed in the Lanham Act. ${ }^{191}$ In this light, China's trademark jurisprudence on apologetic justice is instructive in addressing harm to trademark goodwill and reputation.

China's trademark jurisprudence, as seen through China's Trademark Law, China's Anti-Unfair Competition Law, and China's Civil Law offers a fresh look at how an emerging economic and legal power will address trademark reputation harm. Decisions rendered by Chinese courts applying the three laws ${ }^{192}$ reveal an understanding that names or words used by legal persons in commerce are not merely names or words, but rather, are representations of the legal persons. ${ }^{193}$ The names or words embody the goodwill and reputation that have been carefully cultivated by the legal persons. ${ }^{194}$ A malicious or willful unauthorized use of the names or words harms the plaintiff's reputation and misleads the public. Such use is not just a misappropriation of property rights for which injunction is routinely

Gilson \& LaLonde, supra note 183, at 1019.

190. Heymann, supra note 174, at 1435 ("Although monetary damages are typically awarded in many cases involving reputational injury, such awards tend to serve as a proxy for the degree of emotional harm alleged to have been felt by the plaintiff as a result of the harm to her reputation or, in the case of a business, the loss of selling power of the mark. There is, however, an uneasy fit between monetary awards and various justifications for the legal protection of reputation, particularly those that do not conceive of reputation as a property interest.").

191. To address the shortcomings, crafting remedies for reputation harm, as one scholar has suggested, requires a focus on audience interests that "might counsel more attention to disclaimers, retractions, and other forms of information correction as an appropriate remedy or as a consideration in determining whether further relief from the court is warranted." Heymann, supra note 174, at 1435-36.

192. See supra Part I.

193. Peter Yu has explained how trademark protection is appealing to China as the protection and the concept of "face" are related in Chinese culture:

$[\mathrm{T}]$ rademark protection creates the least friction with the Chinese culture, and the justification for trademark protection, in particular its emphasis on goodwill, is easy for the Chinese to understand. Indeed, the importance of "face" runs deep in the Chinese culture and helps explain why it is important to protect trademarks. Just as "face" is about an individual's self-respect, prestige, and social standing, trademarks, especially well-known ones, provide information about the quality, reputation, and commercial standing of the products.

Peter Yu, From Pirates to Partners (Episode II): Protecting Intellectual Property in PostWTO China, 55 AM. U. L. REV. 901, 998 (2006).

194. Id. 
issued by courts, ${ }^{195}$ and such use is not just an economic harm for which compensatory damages are often fashioned by courts. Even if it is an economic harm, China's trademark jurisprudence shows that damages to trademark reputation may be difficult to establish due to the nature of the harm, and therefore statutory damages are prescribed. ${ }^{196}$ Moreover, unlike U.S. courts' reluctance to award the plaintiff with the defendant's profit in trademark infringement and unfair competition cases, ${ }^{197}$ the China Supreme People's Court instructs the lower courts to disgorge the defendant's profits gained from the infringement. ${ }^{198}$

Most importantly, China's trademark jurisprudence demonstrates that property interest theory and torts liability theory alone do not heal the harm to both the plaintiff and the consuming public caused by the defendant's conduct. Therefore in addition to injunction, damages and costs, the defendant must do more to heal the harm. ${ }^{199}$ The defendant must eliminate the bad effects of the harm done to the plaintiff and to the public. Often, the defendant is ordered to make an apology in relevant newspapers or trade publications within a short period of time after the court's judgment. In many cases, the content of the apology must be approved by the court. ${ }^{200}$

195. Scholars often noted the property interest bestowed on trademarks in the United States and China. See Timothy Lau et al., Protecting Trademark Rights in China through Litigation, 47 Stan. J. INT'L. L. 441, 443-44 (2011) ("Both Chinese and American law share the fundamental understanding of the 'harm' of trademark infringement .... Like modern American trademark law, Chinese law is therefore directed not only to prevent consumer confusion but also to protect trademarks as a property right.").

196. See China's Trademark Law, supra note 35 (prescribing damages for trademark infringement).

197. See generally Danielle Conway-Jones, Remedying Trademark Infringement: The Role of Bad Faith in Awarding an Accounting of Defendant's Profits, 42 SANTA Clara L. REV. 863 (2002) (reviewing cases where courts rule that an award of defendant's profits is only available if the plaintiff establishes that the defendant has infringed the trademark in bad faith).

198. See Opinions of the Sup. People's Ct. on Civil Law, supra note 12 ("In case anyone obtains profits by infringing upon the right to name or title, ... or right to reputation ...., the infringer shall, in addition to compensating the losses of the victim, have his ill-gotten gains taken over."); Trademark Law Interpretation, supra note 33, at art. 14: “The interests obtained from infringement as provided in Article 56, Paragraph 1 of the Trademark Law may be calculated as the product of the sales volume of the infringing commodities and the unit profit of the commodities concerned. In case it is impossible to know the unit profit of the commodity, the unit profit shall be the commodity which is represented by the registered trademark.").

199. I add emphasis here to illustrate that a public apology is not in lieu of an injunction, damages, attorney's fees, and costs. In fact, as seen in Chinese courts' decisions, a public apology is generally the last item in the list of remedies issued by the court. Often, the order of appearance goes first to injunction, then damages, attorney's fees and costs, and lastly, public apology.

200. Hoover, supra note 25 , at 345 (noting that Chinese courts have been ordering 
The defendant must recognize that the plaintiff has the exclusive right to use the trademark or name, admit that he or she has committed a wrongdoing, apologize for the conduct and promise that he or she will not engage in such conduct again. The content of the apology is intended to be more than merely "I am sorry" and is an effort to be sincere and purposeful. ${ }^{201}$ Apologetic justice is not for the plaintiff alone, as the public will also see and read the newspapers or trade publications. ${ }^{202}$

Apologetic justice in trademark jurisprudence is not unique to China. Japanese courts also order apologies in trademark infringement cases. Whereas Japanese courts may order apologies in lieu of or in addition to damages, ${ }^{203}$ Chinese courts order public apologies in addition to injunction, damages, attorney fees, and costs. ${ }^{204}$ Furthermore, Chinese courts only order a public apology in cases where the defendants maliciously or willfully infringed upon the plaintiff's trademark or name. ${ }^{205}$ Also, if the

public apology in trademark infringement cases).

201. Russell Korobkin \& Chris Guthrie, Psychological Barriers to Litigation Settlement: An Experiential Approach, 93 Мich. L. REV. 107, 150 (1994) ("[A] more sincere or more substantive apology could restore equity to the [harmed] relationship.") (citation omitted).

202. U.S. scholars have developed a substantial scholarship on apologies in the last twenty-five years. Apology scholarship demonstrates the positive role of apologies in restorative justice. See generally Max Bolstad, Learning from Japan: The Case for Increased Use of Apology in Mediation, 48 CLEV. ST. L. REV. 545 (2000); Jennifer Robbennolt, Attorneys, Apologies, and Settlement Negotiation, 13 Harv. NeGOT. L. ReV. 349 (2008); Heather Strang \& Lawrence W. Sherman, Repairing the Harm: Victims and Restorative Justice, 2003 UTAH L. REV. 15 (2003); Hiroshi Wagatsuma \& Arthur Rosett, The Implications of Apology: Law and Culture in Japan and the United States, 20 LAW \& SoC'Y REV. 461 (1986); John O. Haley, Comment, The Implication of Apology, 20 LaW \& SOC'Y REV. 499 (1986).

203. H. Stephen Harris, Jr., Competition Law and Patent Protection in Japan: A HalfCentury of Progress, a New Millennium of Challenges, 16 COLUM. J. Asian L. 71, 87 (2002) ("U.S. trademark owners have been surprised to learn that a Japanese court may order a public apology to restore business goodwill, in lieu of (or in addition to) damages."); see also Jay Dratler, Jr., Trademark Protection for Industrial Designs, 1988 U. ILL. L. REV. 887, 968 n.417 (1988) ("In Japan, a public apology for trademark infringement, usually by publication in specified newspapers, is a common remedy in trademark actions.").

204. Another difference is in the calculation of damages. Japanese courts have been reluctant in providing an accounting of defendant's profits, but Chinese courts are instructed to allow the prevailing plaintiff to select defendant's profits, instead of actual economic losses suffered by the plaintiff. See Harris, supra note 203, at 87 (stating that Japanese courts "have been slow to recognize infringement and extremely reluctant to award damages beyond the minimal amount of lost royalty payments"). Compare Harris, supra note 203, with Trademark Law Interpretation, supra note 33, at art. 13-15.

205. See Leah Chan Grinvald, Making Much Ado About Theory: The Chinese Trademark Law, 15 Mich. TeleCOMM. \& TeCH. L. Rev. 53, 92 (2008) (stating that under a distributive theory of trademark law, Chinese courts order public apology in cases where malicious intent was shown on the part of the defendant). 
defendant disobeys the court's order, the plaintiff is permitted to publish a public apology in the name of the defendant and then charge the defendant for the cost. ${ }^{206}$

\section{CONCLUSION}

For the enhancement of fair competition beneficial to the society, trademark law prevents the public from being misled as to the source of goods and services and protects the trademark owner's investment in building a reputation. Injunction and damages are remedies that do not truly consider harm to the public. A public apology that is both sincere and purposeful, in addition to injunction and damages, as seen in China's trademark jurisprudence on reputation and apologetic justice, offers a new dimension to Judge Learned Hand's astute observation on injury to trademark reputation. China's apologetic justice instructs that courts should not indiscriminately order public apologies. Only when willful or malicious infringement of trademark reputation occurs should courts direct the defendant to make a public apology. Whether the United States will consider apologetic justice in trademark reputation cases, however, is a question for future discussion.

206. See generally Ding Xiaochun v. Nantong Educ. Bureau and Jiangsu Fine Arts Publ'g House (Interm. People's Ct. of Nantong City Dec. 19, 2002) (China) (ordering public apology in addition to injunction, damages, and cost against defendant Jiangsu Fine Arts Publishing House; and if the defendant failed to make the public apology, "Ding Xiochun may publish the announcement of apology on Nantong Daily in the name of Jiangsu Fine Arts Publishing House" and the "expenses shall be undertaken by Jiangsu Fine Arts Publishing House"). 